YGOR VINÍCIUS REAL DE LIMA

Variantes genéticas de kappa-caseína em vacas leiteiras e características físico-químicas e de composição do leite 


\author{
YGOR VINÍCIUS REAL DE LIMA
}

\title{
Variantes genéticas de kappa-caseína em vacas leiteiras e características físico-químicas e de composição do leite
}

Dissertação apresentada ao Programa de PósGraduação em Nutrição Animal da Faculdade de Medicina Veterinária e Zootecnia da Universidade de São Paulo para obtenção do título de Mestre em Medicina Veterinária

\section{Departamento:}

Nutrição e Produção Animal

Área de concentração:

Nutrição Animal

Orientador:

Prof. Dr. Marcos Veiga dos Santos

\section{Pirassununga}


Autorizo a reprodução parcial ou total desta obra, para fins acadêmicos, desde que citada a fonte.

\section{DADOS INTERNACIONAIS DE CATALOGAÇÃO-NA-PUBLICAÇÃO}

(Biblioteca da Faculdade de Medicina Veteninária e Zootecnia da Universidade de São Paulo) caracteristicas fisico-químicas e de composição do leite / Ygor Vinícius Real de Lima. - Pirassununga : Y. V. R. Lima, 2005. $84 \mathrm{f}$ : il.

Dissertação (mestrado) - Universidade de São Paulo. Faculdade de Medicina Veterinária e Zootecnia. Departamento de Nutrição e Produção Animal, 2005.

Programa de Pós-graduação: Nutrição Animal.

Área de concentração: Nutrição Animal.

Orientador: Prof. Dr. Marcos Veiga dos Santos.

1. Leite. 2. Vaca leiteira. 3. Composição. 4. Kappa-caseina. 5. Polimorfísmo. I. Título. 


\title{
PARECER DA COMISSÃO DE BIOÉTICA
}

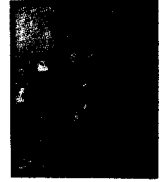

\author{
UNIVERSIDADE DE SÃO PAULO \\ Faculdade de Medicina Veterinária e Zootecnia \\ Cidade Universitária "Armando de Salles Oliveira" \\ Comissão Bioética

\section{CERTIFICADO}

Certificamos que o Projeto intitulado “Correlação entre variantes genéticas de beta-lactoglobulina e kappa-caseína em rebanhos leiteiros comerciais e a ocorrência de alterações das características físicoquímicas e de composição do leite", Protocolo n470/2004, não utilizando animais, sob a responsabilidade do Prof. Dr. Marcos Veiga dos Santos, está de acordo com os princípios éticos de experimentação animal da Comissão de Bioética da Faculdade de Medicina Veterinária e Zootecnia da Universidade de São Paulo e foi aprovado "ad referendun".

(We certify that the Research "Correlation between genetic variants of betalactoglobulin and kappa-casein in dairy herds and the occurrence of alterations in physical-chemical composition of milk". protocol number 470/2004, under the responsibility of Prof. Dr. Marcos Veiga dos Santos, agree with Ethical Principles in Animal Research adopted by Bioethic Commission of the Faculty of Veterinary Medicine and Zootechny of University of São Paulo and was approved "ad referendun", meeting.

São Paulo, 13 de maio de 2004

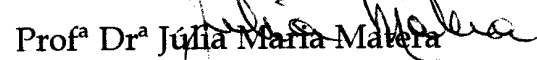

Presidente da Comissão de Bioética

FMVZ/USP 


\section{FOLHA DE AVALIAÇÃO}

Nome do autor: Lima, Ygor Vinícius Real de

Tíitulo:Variantes genéticas de kappa-caseína em vacas leiteiras e características físicoquímicas e de composição do leite

Dissertação apresentada ao Programa de PósGraduação em Nutrição Animal da Faculdade de Medicina Veterinária e Zootecnia da Universidade de São Paulo para obtenção do título de Mestre em Medicina Veterinária

Data:

\section{Banca Examinadora}

Prof. Dr.: Instituição

Assinatura: Julgamento:

Prof. Dr.: Instituição

Assinatura: Julgamento:

Prof. Dr.: Instituição

Assinatura: Julgamento: 
"Aos meus pais pelo amor, dedicação e amizade." 


\section{AGRADECIMENTOS}

Ao Prof. Dr. Marcos Veiga dos Santos, da FMVZ/USP, pela confiança, incentivo, amizade e convívio que tivemos ao longo desta jornada, tornando possível o desenvolvimento deste e de muitos outros trabalhos.

A Faculdade de Medicina Veterinária e Zootecnia da Universidade de São Paulo pelo acolhimento.

A toda equipe do laboratório de Tecnologia de Produtos de Origem Animal, VNPFMVZ, Zeca, Lucinéia, Bruno, Adriana e Camilla; que fazem parte deste trabalho e sem os quais este não teria sido realizado. Além dos momentos de convivência familiar que passamos juntos durante esta jornada. Muito obrigado.

A Raquel pelo apoio fundamental em diversos momentos do projeto, além da amizade em muitos momentos agradáveis e difíceis. Obrigado.

Ao Arlindo (Minhoca) pelo auxilio na escolha das fazendas a serem amostradas, pela convivência, amizade e auxilio em diversos momentos deste e outros trabalhos desenvolvidos durante o mestrado. Obrigado

Aos estagiários que passaram pelo laboratório durante a execução deste e outros experimentos realizados: Fabrício (Cuberto), Montemar (Fruta), Gustavo (Xups), Luis (Cuxpe), Flavio, Rafael, Ariane, Estela, alunos de graduação das turmas 67 e 68 da FMVZUSP e muitos outros de igual e fundamental importância para a execução deste.

Aos eternos amigos Alex e Alexandre pelo convívio constante e apoio durante a execução deste e de outros projetos.

A todos os pós-graduandos pelos momentos de diversão, seriedade, companheirismo e amizade. 
A todos os professores e funcionários do departamento de Nutrição e Produção Animal da FMVZ-USP.

Aos funcionários do Campus Administrativo de Pirassununga pela concessão de Bolsa moradia durante a execução deste.

À Fundação de Amparo à Pesquisa no Estado de São Paulo (FAPESP), pelo auxílio financeiro para a realização desta pesquisa.

Ao CNPq pela concessão de Bolsa pesquisa. 


\section{RESUMO}

LIMA, Y. V. R. de. Variantes genéticas de kappa-caseína em vacas leiteiras e características físico-químicas e de composição do leite. [Kappa-casein polimorphism in dairy cows and, physical-chemical properties and composition of milk.]. 2005. $84 \mathrm{f}$. Dissertação (Mestrado em Medicina Veterinária) - Faculdade de Medicina Veterinária e Zootecnia, Universidade de São Paulo, Pirassununga, 2005.

Os objetivos gerais do presente estudo foram avaliar o efeito do polimorfismo genético da kappa-caseína, da raça e da estação do ano sobre as características físico-químicas (acidez, pH e crioscopia), composição (gordura, lactose, sólidos totais, contagem de células somáticas, uréia, proteína bruta, proteína verdadeira, nitrogênio não protéico e nitrogênio não caseinoso) e estabilidade do leite. Foram selecionados 11 rebanhos leiteiros comerciais, sendo cinco deles da raça Holandesa e seis da raça Girolanda, dos quais foram amostradas em média 122 vacas em lactação por rebanho, totalizando 1350 vacas amostradas em três períodos: 2 no período seco e 1 no período chuvoso. As vacas selecionadas foram analisadas quanto a composição e propriedades físico-químicas do leite, assim como para a determinação do polimorfismo de kappa-caseína. O presente trabalho foi dividido em dois estudos, no primeiro avaliou-se os efeitos da raça e estação do ano sobre características físico-químicas, composição e estabilidade do leite. Foi observado efeito de raça sobre acidez titulável, pH, lactose, uréia e estabilidade do leite. O efeito de sazonalidade mostrou-se significativo sobre $\mathrm{pH}$, crioscopia, teores de lactose, uréia, proteína bruta, sólidos totais, contagem de células somáticas, proteína verdadeira, caseína, nitrogênio não protéico e estabilidade térmica do leite. Em animais da raça Girolanda, foram observados no período seco maiores teores de sólido totais. O ponto crioscópico do leite sofreu efeito do período de coleta somente em animais da raça Holandesa, onde valores mais altos foram observados durante o período seco. 
Os teores de lactose apresentaram maiores médias no período seco em animais da raça Holandesa. Os teores de uréia sofreram efeito de raça e período de coleta estudado. A proteína bruta do leite sofreu efeito dos fatores raça e período de coleta, sendo que vacas da raça Holandesa e Girolanda apresentam maiores teores no período seco. A concentração de caseína do leite sofreu efeito significativo do período de coleta. A estabilidade térmica do leite sofreu influência da raça, pois o leite de vacas da raça Holandesa mostraram-se mais estáveis do que os da raça Girolanda. A sazonalidade é um fator determinante para a estabilidade do leite, pois o leite mostrou-se mais estável no período chuvoso que em período seco. No segundo estudo foram avaliados o polimorfismo genético da kappa-caseína em vacas Holandesas e Girolandas e o efeito deste sobre características físico-químicas, de composição e estabilidade térmica do leite. A frequiência do alelo A foi maior do que a do alelo B no que diz respeito ao gene da kappa-caseína. Com relação às características físico-químicas do leite, não houve efeito do polimorfismo do gene da kappa-caseína sobre teores de gordura, sólidos totais, lactose, contagem de células somáticas e uréia do leite. Não foram observados efeitos do polimorfismo genético do gene para kappa-caseína sobre a composição protéica do leite, sendo que teores de proteína bruta, nitrogênio não protéico, nitrogênio não caseinoso e proteína verdadeira não sofrem influência. A estabilidade do leite frente à prova do álcool não sofreu influencia do polimorfismo genético de kappa-caseína.

Palavras-chave: Leite. Vaca leiteira. Composição. Kappa-caseína. Polimorfismo. 


\begin{abstract}
LIMA, Y. V. R. de. Kappa-casein polimorphism in dairy cows and, physico-chemical properties and composition of milk. [Variantes genéticas de kappa-caseína em vacas leiteiras e características físico-químicas e de composição do leite]. 2005. 84 f. Dissertação (Mestrado em Medicina Veterinária) - Faculdade de Medicina Veterinária e Zootecnia, Universidade de São Paulo, Pirassununga, 2005.
\end{abstract}

The objective of this study were to determine the effects of kappa-casein gene polymorphisms, breed and season on physical-chemical properties (acidity, $\mathrm{pH}$ and cryoscopy), composition (fat, lactose, total solids, somatic cells count, urea, crude protein, true protein, non protein nitrogen and non casein nitrogen) and stability of milk. For this aim 11 dairy herds were selected, six of them composed of Girolando cows and five from Holstein cows, in average milk samples were taken of 112 cows from each herd, collected three times: twice in dry season and once on rainy season. Each cow were analyzed for milk composition, physico-chemical properties, and to determine its kappa-casein polymorphism. This study was divided in two, the first one analyzed possible breed and season effects over milk physicochemical characteristics, composition and stability. Breed effect was observed over acidity, $\mathrm{pH}$, lactose, urea and milk stability. Season effects was significant for $\mathrm{pH}$, cryoscopy, lactose, urea, CP, total solids, SCC, TP, casein, EqNPN and heat milk stability. In cows Girolando it was observed highest total solids in dry season. Milk cryoscopy had season effects only on Holstein cows, with highest results in dry season. Lactose concentration was greatest in Holstein cow in dry season. Urea concentration showed breed and season effect on this study. Crude protein was affected by breed and season, in dry season the concentration were highest for Holstein and Girolanda. Casein milk concentration demonstrated season effect. Heat milk stability showed breed stability, milk from Holstein cow were more stable that milk from Girolanda cows. Season is a determinant factor for milk stability, milk showed more stable in 
rainy season than during dry period. The second study analyzed: kappa-casein gene polymorphisms in Holstein and Girolando cows and its effects over milk physico-chemical characteristics, milk composition and milk heat stability. Kappa-casein allele A had a higher frequency, than allele B, in Girolando and Holstein cows in comparison with other polymorphisms. No effect of kappa-casein polymorphism was observed on milk phisicochemical characteristics and on milk fat, total solids, lactose, SCC, and milk urea. There were no difference for milk protein composition (EqNPN, NCNC, TP, casein and EqNCN) for kappa-casein polymorphism. Milk alcohol stability did not showed effect of gene polymorphism.

Key words: Milk. Dairy cow. Composition. Kappa-casein. Polymorphism. 


\section{LISTA DE ABREVIATURAS}

C coagulado

CCS contagem de células somáticas

DNA ácido desoxirribonucléico

DP desvio padrão

EqNNP equivalente nitrogênio não protéico

NC não coagulado

NNC nitrogênio não caseinoso

NNP nitrogênio não protéico

NT nitrogênio total

NUL nitrogênio uréico do leite

${ }^{\circ} \mathrm{D} \quad$ graus dornic

${ }^{\circ} \mathrm{GL} \quad$ graus Gay Lussac

PB proteína bruta

PCR reação em cadeia de polimerase

pH potencial de hidrogênio

PT proteína total

PV proteína verdadeira

RFLP "restriction fragment length polymorphism"

UHT temperatura ultra alta 


\section{SUMÁRIO}

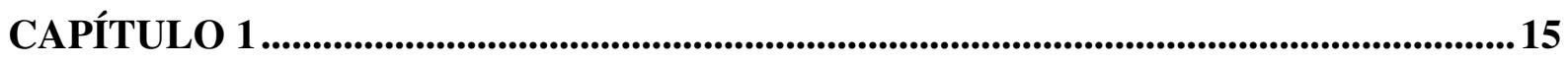

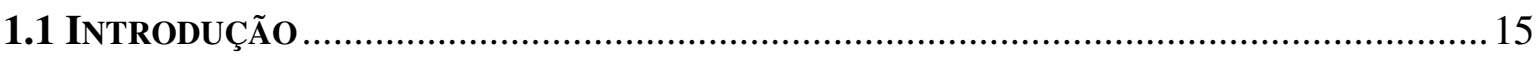

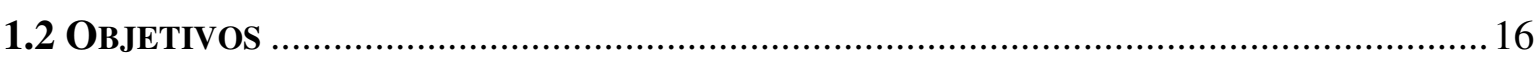

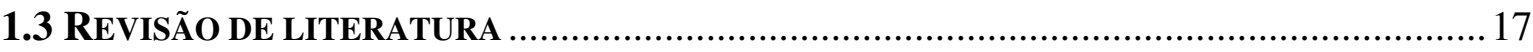

1.3.1 Composiçãa e características físico-químicas do leite ........................................ 17

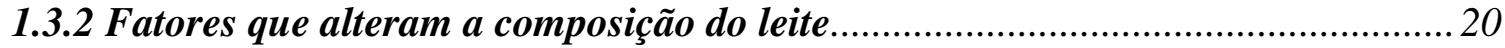

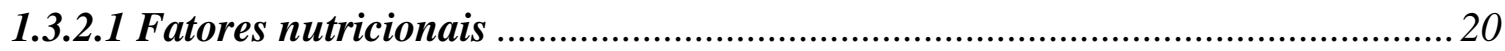

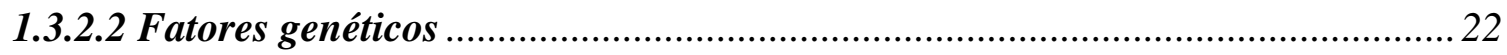

1.3.2.3 Fatores ambientais que interferem na secreção láctea .................................. 25

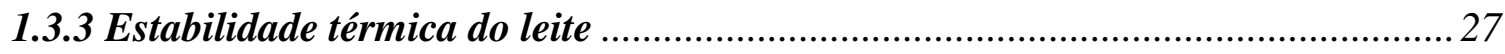

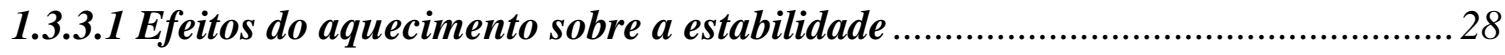

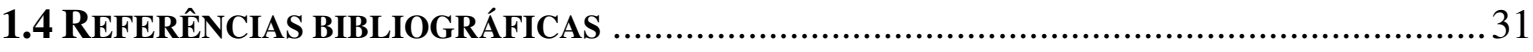

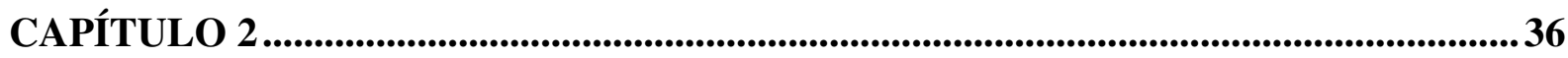

2.1 INTRODUÇÃ

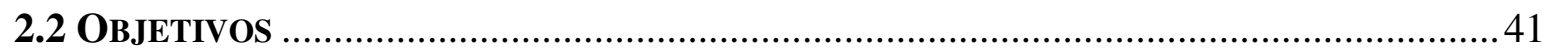

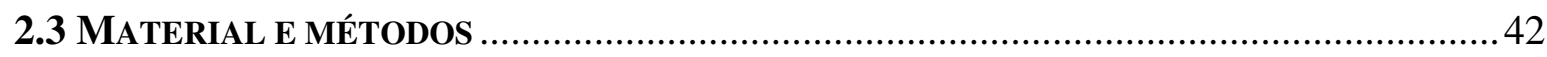

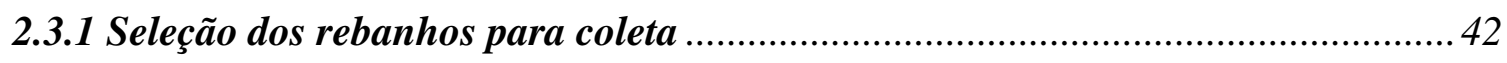

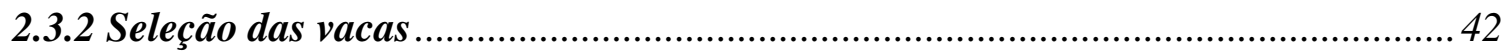

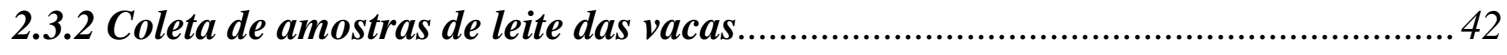

2.3.3 Delineamento experimental e análise estatística ............................................... 43

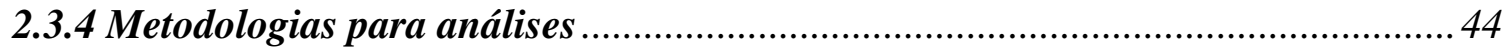

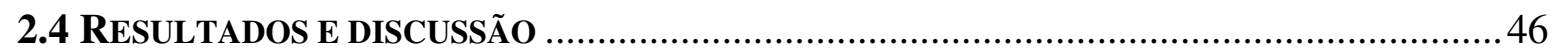

2.4.1 Características físico-químicas e de composição. ............................................... 46

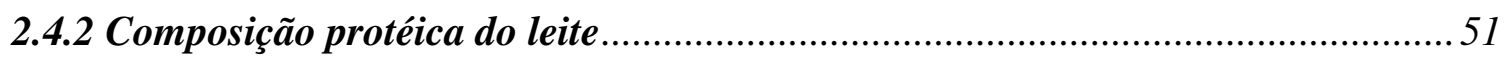

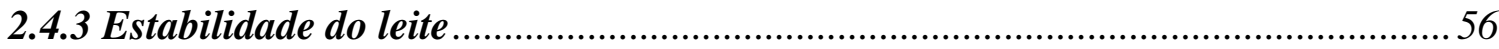

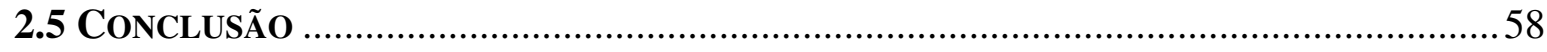

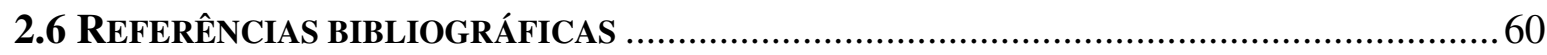

CAPÍTULO 3 ...........................................................................................................................6 64 
3.1 INTRODUÇão 65

3.2 OBJetivos 68

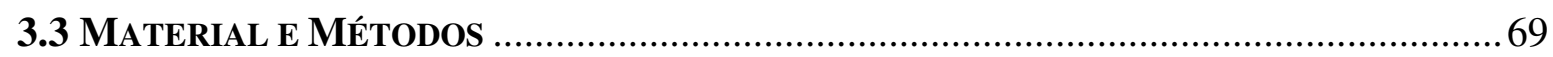

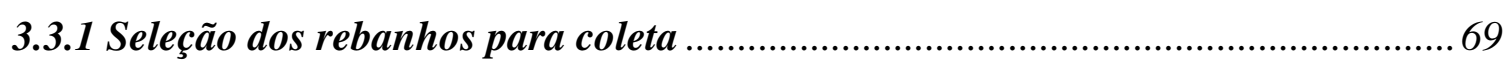

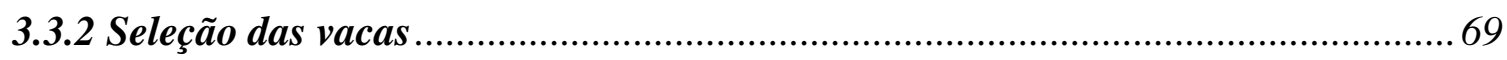

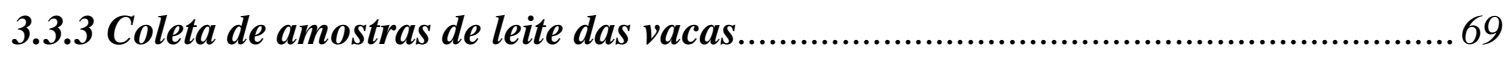

3.3.4 Delineamento experimental e análise estatística ................................................ 70

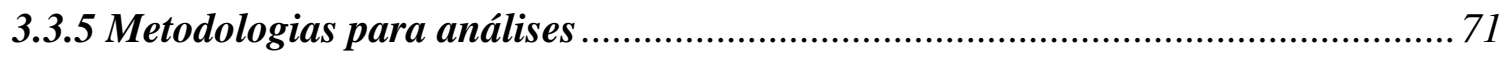

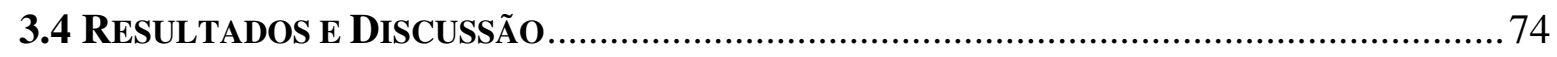

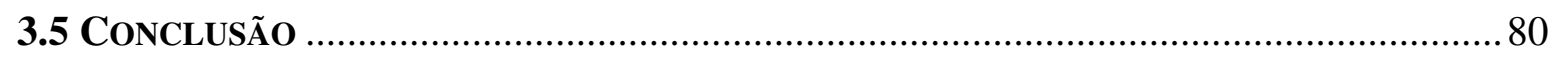

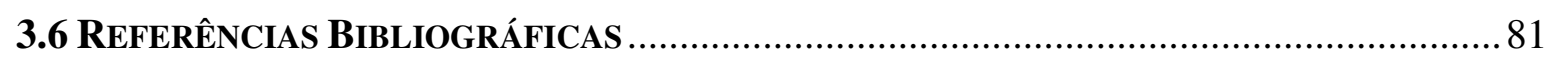




\section{CAPÍTULO 1}

\subsection{Introdução}

A importância do estudo da composição do leite, assim como dos fatores que a influenciam, tem grande relevância para a indústria de laticínios, pois esta tem o leite como matéria prima essencial para a fabricação de vários derivados lácteos. O leite normalmente é composto por água $(87,3 \%)$, suspensão coloidal de proteína $(3,4 \%)$ ligadas a Ca e P; emulsão de glóbulos de gordura $(3,5 \%)$, lactose $(4,8 \%)$, sais minerais $(0,8 \%)$ e vitaminas. É um alimento altamente perecível, tendo suas características físicas, químicas e biológicas originais facilmente alteradas por uma série de mecanismos, os quais podem ocorrer desde a fase de produção primária até a manipulação no processamento industrial. Além disso, é um fluído biológico extremamente variável e dependente de características nutricionais, raça, sazonalidade, sanidade e estágio de lactação.

Com o avanço tecnológico da indústria láctea, a habilidade do leite bovino em resistir a temperaturas de processamento é uma das mais importantes características para sua industrialização. Desta forma, é de grande importância determinar quais fatores influenciam a estabilidade térmica do leite.

A presente dissertação foi subdividia em três capítulos para melhor compreensão, sendo o primeiro referente a aspectos gerais do trabalho e revisão de literatura sobre o tema abordado; o segundo capítulo aborda o efeito da raça e sazonalidade sobre composição, características físico-químicas e estabilidade do leite em rebanhos leiteiros comerciais; e o último capítulo trata do efeito do polimorfismo genético da kappa-caseína sobre características físico-químicas, composição e estabilidade térmica do leite de rebanhos leiteiros comerciais. 


\subsection{Objetivos}

Os objetivos gerais do presente estudo foram o de relacionar o efeito do polimorfismo genético da kappa-caseína, da raça, da estação do ano e do manejo nutricional sobre as características físico-químicas e de composição do leite de vacas das raças Holandesa e Girolanda. Os objetivos específicos do presente estudo foram:

a) Avaliar o efeito da raça (Holandesa e Girolanda) sobre as características físicoquímicas (acidez, pH e crioscopia), composição (gordura, lactose, sólidos totais, CCS, uréia, PB, PV, NNP, NNC) e estabilidade do leite;

b) Determinar o efeito da estação do ano (seca e chuvosa) sobre características físicoquímicas (acidez, pH e crioscopia), composição (gordura, lactose, sólidos totais, CCS, uréia, PB, PV, NNP, NNC) e estabilidade do leite;

c) Avaliar o efeito do polimorfismo genético de kappa-caseína sobre as características físico-químicas (acidez, pH e crioscopia), composição (gordura, lactose, sólidos totais, CCS, uréia, PB, PV, NNP, NNC) e estabilidade do leite. 


\subsection{Revisão de literatura}

\subsubsection{Composição e características físico-químicas do leite}

O leite é uma combinação de várias substâncias em solução como a lactose, sais minerais e vitaminas; emulsão de gordura e suspensão coloidal de micelas de caseína, ligadas ao cálcio e fósforo. O leite, contudo, é um produto extremamente perecível, tendo suas características físicas, químicas e biológicas originais facilmente alteradas pela ação de microorganismos ou, pela manipulação que ocorre durante o processamento industrial (DÜRR, 2004).

As proteínas do leite podem ser classificadas em dois grandes grupos: as caseínas e as proteínas do soro. A caseína pode ser definida como a fração da proteína do leite que sofre precipitação em $\mathrm{pH}=4,6$; enquanto que o restante das proteínas que não sofrem esta precipitação são chamadas coletivamente de proteínas do soro (FARREL et al, 2004 e VILLOSLADA, OLIVARES e XAUS, 2005). A caseína, sintetizada nas células epiteliais da glândula mamária, consiste de 4 principais classes, as quais compõe aproximadamente $80 \%$ do total de proteínas do leite, o que determina uma concentração média de 24-28 mg/mL. Dentre as quatro principais proteínas do soro, duas são sintetizadas na glândula mamária ( $\beta$ lactoglobulina e a $\alpha$-lactoalbumina), enquanto as outras duas são de origem do sangue (albumina sérica e imunoglobulinas). Outras proteínas do soro incluem a lactoferrina, transferrina e enzimas (plasmina e fosfatase alcalina). No leite normal, a $\beta$-lactoglobulina é a proteína do soro presente em maior concentração $(2-4 \mathrm{mg} / \mathrm{mL})$, seguida pela $\alpha$-lactalbumina (1-1.5 $\mathrm{mg} / \mathrm{mL})$, enquanto que a albumina sérica e as imunoglobulinas apresentam, respectivamente, as seguintes concentrações: 0,1-0,4 e 0,6-1,0 mg/mL (FARREL et al, 2004).

O leite apresenta, além das proteínas e peptídeos, uma fração de compostos nitrogenados não-protéicos (NNP), que segundo Walstra e Jenness (1984) pode perfazer 
aproximadamente 5\% do total de nitrogênio do leite. Estes compostos são principalmente de origem sangüínea, incluindo substâncias como a uréia e a creatinina. De acordo com Depeters e Cant (1992), a maior porção do NNP encontra-se sob a forma de uréia (48\%), o qual entra livremente na glândula mamária, por difusão, para equilibrar sua concentração com a do plasma sangüíneo.

Já a lactose é um dissacarídeo que representa cerca de 4,8\% do leite de vaca e é sintetizada unicamente na glândula mamária a partir de uma ligação glicosídica do tipo $\beta(1-4)$ entre glicose e galactose (FOX e MC SWEENWEY, 1998). Como regra geral, a menos que os animais estejam muito subnutridos, a concentração de lactose no leite não pode ser alterada por fatores externos à glândula. Isto se deve ao fato de ser a lactose uma das responsáveis pela manutenção da pressão osmótica na glândula mamária de forma que, maior produção de lactose determina maior produção de leite, com o mesmo teor de lactose (PERES, 2001). Segundo Fredeen (1996) apesar da alimentação e fatores ambientais responderem por aproximadamente $50 \%$ das variações de gordura e proteína do leite, esta praticamente não alteram o conteúdo de lactose.

Quanto ao teor de gordura, o leite bovino apresenta aproximadamente 3,5\%, sendo a nutrição energética para o neonato sua principal função biológica. É sintetizada na glândula mamária a partir de ácidos graxos de origem sanguínea e da própria glândula, formando os triacilglicerídios que somam aproximadamente $98 \%$ da quantidade total de gordura do leite. Os principais fatores que influenciam o teor de gordura do leite são: raça, individualidade animal, estágio de lactação, alimentação, escore corporal, sanidade da glândula mamária, intervalo entre lactações e ponto da ordenha em que a amostra é coletada (FOX e MCSWEENEY, 1996; LANE et al, 1997).

Os sais presentes no leite são oriundos do sangue, e representam cerca de $0,8 \%$. São eles: citrato (1750 mg/L), sulfato (100 mg/L), carbonato (200 mg/L), bicarbonato de sódio, 
sódio (500 mg/L), potássio (1450 mg/L), cálcio (1200 mg/L) e magnésio (130 mg/L). Outros 20 elementos já foram identificados no leite, mas apresentam concentrações variáveis e são influenciados por uma série de fatores não esclarecidos (FOX e MC SWEENWEY, 1998).

De maneira geral, a qualidade do leite pode ser avaliada através de uma série de propriedades que afetam, direta ou indiretamente, a adequação ao processamento industrial, a segurança e a demanda do produto. Um leite de boa qualidade deve apresentar as seguintes características: sabor agradável, alto valor nutritivo, ausência de agentes patogênicos e contaminantes (antibióticos, pesticidas e adição de água), reduzida contagem de células somáticas e baixa carga microbiana. Os principais critérios utilizados para caracterizar as propriedades físico-químicas do leite são, de acordo com Fonseca e Santos (2000):

a) Densidade: avalia a concentração de componentes dissolvidos ou em suspensão (sólidos não gordurosos) e o teor de gordura do leite. Pode variar de 1,024 a 1,036 g/cm ${ }^{3}$, no entanto a faixa mais comum é de 1,028 a $1,032 \mathrm{~g} / \mathrm{cm}^{3}$;

b) Crioscopia: uma vez que o leite apresenta uma série de substâncias dissolvidas, seu ponto de congelamento é inferior a $0^{\circ} \mathrm{C}$, na faixa de $-0,512^{\circ} \mathrm{C}\left(-0,530^{\circ} \mathrm{H}\right)$;

c) $\mathrm{pH}$ : pode variar de 6,60 a 6,80; contudo este valor está normalmente situado entre 6,65 e 6,72. O leite normal possui elevada capacidade tamponante, devido à presença de dióxido de carbono, proteínas, fosfato, citrato e lactato;

d) Acidez titulável (Dornic): a acidez do leite pode ser medida pela titulação com solução de hidróxido de sódio (concentração N/9). Assim, o leite normal apresenta faixa de variação de $16-18^{\circ} \mathrm{D}$ (graus Dornic). O teste de Dornic é o mais utilizado para avaliação de acidez do leite, e tem por objetivo detectar aumentos na concentração de ácido lático. Sua concentração é resultado da fermentação da lactose por bactérias mesófilas, e pode indicar qualidade microbiológica da matéria-prima. 


\subsubsection{Fatores que alteram a composição do leite}

A composição química do leite é influenciada principalmente pela nutrição, sistema de manejo, raça, nível de seleção genética, sanidade da glândula mamária (FONSECA e SANTOS, 2000), assim como pelos fatores fisiológicos da própria lactação (FOX e MC SWEENWEY, 1998).

Segundo Dürr (2004), a concentração de gordura e proteína depende do tipo e da quantidade de alimento que o animal ingere, além do potencial genético para a produção desse sólidos. Assim, pode ser alterada pelo manejo nutricional ou pela exploração da variabilidade genética dos animais.

\subsubsection{Fatores nutricionais}

Alterações na alimentação são responsáveis, principalmente, por mudanças nas concentrações de gordura e proteína do leite (SANTOS et al, 2001a; SANTOS et al, 2001b). O manejo e o balanceamento nutricional desempenham importante papel na composição do leite. Considerando animais da mesma raça e potencial produtivo, os principais fatores associados à composição são: consumo de matéria seca, qualidade e digestibilidade da fibra e a relação energia/proteína da dieta.

Nas regiões tropicais, é muito comum o uso de pastagens na alimentação de ruminantes. A baixa densidade de nutrientes e a reduzida digestibilidade da fibra limitam consideravelmente o consumo de matéria seca durante a época menos chuvosa (FONSECA e SANTOS, 2000), levando ao desbalanço entre a energia e proteína, assim como à carência de minerais (PONCE et al, 1999). Nestas circunstâncias, ocorre diminuição da produção de leite e incremento no conteúdo de gordura do leite. No entanto, quando este déficit é pequeno, não há alteração nos demais componentes do leite (PONCE et al, 1999). Normalmente, alterações na fração dos carboidratos na dieta, favorecem a concentração de gordura, mas reduzem a 
concentração de proteína no leite. Por outro lado, dietas com alto teor de concentrados, ou com fontes de carboidratos mais fermentáveis no rúmen favorecem a produção de proteína no leite (THEURER et al, 1999). A maior disponibilidade de ácido propiônico no rúmen, que estimula a secreção de insulina; e uma fermentação ruminal mais ativa com maior produção de proteína microbiana são fatores que contribuem para a ocorrência deste fenômeno. Ao mesmo tempo, esse tipo de dieta reduz o $\mathrm{pH}$ ruminal, o que favorece a síntese de ácidos graxos trans no rúmen (GRANT et al, 1990a; GRANT et al, 1990b; PIPEROVA et al, 2000). Alguns desses ácidos graxos trans têm a capacidade de inibir enzimas lipogênicas no tecido mamário e reduzir a concentração de gordura no leite (PIPEROVA et al, 2000). A baixa concentração de gordura no leite pode ser indicativa de acidose ruminal (NOCEK, 1997).

O sistema de manejo extensivo está associado à menor produção de leite, assim como baixas concentrações de gordura e proteína, desencadeadas pela menor disponibilidade de MS ao animal, sendo que a suplementação com concentrado associada ao fornecimento adequado de forragens evita tais alterações na produção e composição do leite (BARGO et al, 2002).

Em relação as frações nitrogenadas do leite, as modificações na composição podem ocorrer em função do teor protéico e de uréia fornecido na dieta (DEPETERS e CANT, 1992). Fernandez et al (1997) postulam que tal fração poderá ser afetada, comprometendo suas propriedades de processamento quando do uso de altos teores de NNP (50\% da PB). Foram observadas diferenças nos teores de proteína e gordura do leite quando da comparação de dietas com PV ou uréia em dietas com silagens de alfafa e milho (BRODERICK et al, 1993). SANTOS et al (1998) relataram que a substituição, parcial ou total da PV por uréia, em um total de 23 comparações, não afetou a produção de leite em 20 destes estudos e aumentou o teor de proteína em 5 deles.

A concentração de nitrogênio uréico no leite (NUL) é uma boa ferramenta para o monitoramento da nutrição protéica em animais leiteiros, pois apresenta boa correlação com a 
concentração de nitrogênio uréico no plasma (NUP) ou no sangue (NUS) (JONKER et al, 1999). A determinação da concentração de nitrogênio uréico no leite (NUL), através da amostragem de leite durante as ordenhas, representa um mecanismo simples, rápido e barato de avaliação do "status" nutricional de vacas em lactação (BUTLER et al, 1995; MEYER et al, 2004). Sendo que o NUL demonstra principalmente a adequação da relação entre o nitrogênio e a energia da dieta (BRODERICK e CLAYTON, 1997). Entretanto, outros fatores podem também influenciar a concentração de uréia do leite, como: produção leiteira, idade da vaca, estágio de lactação (CARLSSON et al, 1995), peso vivo (JONKER et al, 1998) e sistema de pastejo (GIELEN et al, 1989). As percentagens de proteína do leite (JONKER et al, 1999) e gordura do leite (JONKER et al, 1998) também têm sido associadas a concentração de NUL. Variações diurnas da concentração de NUL foram encontradas por alguns pesquisadores (GUSTAFSSON e PALMQUIST, 1993; ROSELER et al, 1993), assim como variações sazonais sobre NUL também foram relatadas por Carlsson e Pehrson (1993).

\subsubsection{Fatores genéticos}

A maioria das características de importância econômica em bovinos é resultante da ação de genes e ambiente, e são denominadas poligênicas, quantitativas ou de múltipla herança. O fenótipo resultante apresenta variação contínua ao invés de classes fenotípicas discretas. Caracteres de produção, qualidade, precocidade, dentre outros, são exemplos de herança quantitativa. Progressos contínuos da genética molecular têm permitido a localização de marcadores genéticos ao longo do genoma de interesse e, com a utilização destes marcadores, inicia-se o trabalho de inferência sobre os loci de características quantitativas (FARIA et al, 2000).

A principal meta dos cientistas da área da genética molecular é construir mapas de ligação suficientemente densos que forneçam suporte para os estudos de características de 
importância econômica, cuja expressão está relacionada a genes simples ou a loci de características quantitativas, os quais contribuem para a variação observada em algumas destas características. Estes mapas de ligação podem ser usados para desenvolver estratégias para a seleção assistida por marcadores (ROTHSCHILD e SOLLER, 1999), principalmente devido ao fato da possibilidade de rápida decisão no uso ou exclusão de um animal para reprodução e, ao mesmo tempo, em demonstrar seu potencial para características de produção (MEDRANO e AGUILARCORDOVA, 1990). Em bovinos, entre os marcadores genéticos que podem ser utilizados para seleção, alguns exemplos são a kappa-caseína e betalactoglobulina, os quais são regulados por um par de genes (A e B) com transmissão codominante.

Relatos sobre a associação entre fenótipo da kappa-caseína e composição do leite são controversos (LIN et al, 1986). Ng-Kwai-Hang et al (1990), ao estudar dados de um período de dois anos, de 1908 vacas Holandesas, relatou que animais kappa-caseína B apresentavam teor de gordura no leite maior que os animais kappa-caseína A. Entretanto, estes mesmos autores ao realizar trabalho semelhante, em 1990, em animais da raça Holandesa, observaram maior produção de gordura pelos animais A. Quanto ao percentual de proteína, alguns autores relatam ausência de efeito das variantes do gene para kappa-caseína para quantidade de proteína produzida (HAENLEIN et al, 1987). No entanto, outros estudos desenvolvidos demonstram o que o alelo B da kappa-caseína em bovinos está correlacionado com maior produção de proteínas no leite, quando comparados ao alelo A (MEDRANO e AGUILARCORDOVA, 1990; STEVANOVIC et al, 2000). Em bovinos, o genótipo BB da kappa-caseína foi associado a características de processamento superiores, sendo que o uso do leite de vacas com genótipo BB para kappa-caseína, resultou em menor tempo de coagulação para o preparo de queijo, formação de coágulo com maior densidade devido ao menor tamanho da micela, assim como maior produção de queijo em relação ao leite de vacas com 
genótipo AA para kappa-caseína (VAN EENENNAAM e MEDRANO, 1991a; VAN EENENNAAM e MEDRANO, 1991b).

A composição protéica específica do leite é de interesse da indústria láctea, pois o consumo de queijo no Brasil passou de 360 mil toneladas em 2003 para 480 mil toneladas em 2004 (USDA), e no mundo houve um crescimento da ordem de 10\% no mesmo período, sendo que a produção deste derivado lácteo depende da presença de caseína no leite. Existem, atualmente métodos precisos de identificação das frações de caseína, assim como técnicas de engenharia genética para induzir a síntese direcionada de $\kappa$-caseínas as quais apresentam maior rendimento na industrialização do queijo (DEPETERS e CANT, 1992).

A composição do leite de vacas de diferentes genótipos para proteínas do leite pode variar quanto ao polimorfismo da beta-lactoglobulina (MACKLE et al, 1999). Por exemplo, o leite de vacas do genótipo AA de beta-lactoglobulina apresenta $28 \%$ mais proteína do soro, $7 \%$ menos caseína, $11 \%$ mais gordura e $6 \%$ menos de sólidos totais que o leite das vacas do genótipo BB (HILL, 1993). De acordo com Mackle et al (1999), o leite de vacas do genótipo BB da kappa-caseína apresentou maiores concentrações de proteína e de caseína quando comparados com o leite de vacas com genótipo AA, o que indica que o leite das vacas BB apresenta maior potencial para a produção de queijos. Desta forma, estas variações entre vacas de fenótipos diferentes podem resultar em alterações da matéria-prima para a fabricação de queijos e outros derivados lácteos, sendo possível o seu uso como ferramenta para a seleção genética de vacas leiteiras.

As vacas com genótipos BB para kappa-caseína e BB para beta-lactoglobulina produzem leite com composição protéica que aumenta o rendimento de fabricação de queijo. Uma vez que a dieta apresenta efeito mínimo sobre a composição protéica do leite, conclui-se que o aumento da produção de queijo pela modificação da proteína láctea pode ser alcançada 
mais rapidamente através da seleção de vacas com os genótipos BB para alfa-caseína assim como BB para beta-lactoglobulina (BOBE et al, 2004).

Vários trabalhos relatam que o polimorfismo da beta-lactoglobulina tem uma resposta marcante na produção de leite destes animais. Desta forma, vacas com genótipo BB produzem leite com maior quantidade de caseína, contribuindo para seu melhor aproveitamento quando do processamento (HILL, 1993).

\subsubsection{Fatores ambientais que interferem na secreção láctea}

As características de produção são influenciadas direta e indiretamente pela temperatura, luminosidade, precipitação pluviométrica, e conseqüentemente pela qualidade diferenciada das pastagens (BANKS et al, 1984). A produção de leite na raça Holandesa é muito variável em nosso meio. A resposta fenotípica é modificada em função das diferenças encontradas no genótipo dos animais, no meio ambiente onde vivem e, ainda como conseqüência da interação entre genótipo e ambiente (RORATO et al, 2000).

Matos et al (1997), estudando 4 rebanhos Holandeses, no Rio Grande do Sul, de 1988 a 1994, em regime semi-extensivo, mostrou que as maiores produções de leite e gordura foram observadas nos meses de abril a setembro, quando as condições climáticas são favoráveis aos animais da raça Holandesa, além da possível suplementação alimentar durante os meses de outono-inverno, comuns nesta fase do ano.

Allore et al (1997) mostraram que rebanhos na região Nordeste dos EUA apresentaram produção de leite, gordura e proteína verdadeira, assim como percentual de proteína verdadeira e contagem de células somáticas maiores durante primavera (março a junho) do que no outono (agosto a novembro). Naikare et al (1992) estudaram os fatores que afetam a produção, assim como o percentual de gordura em vacas cruzadas com a raça Girolanda. A estação do ano afetou as duas características estudadas, de modo que a percentagem e 
produção de gordura para o verão (março a junho) foram menores $(4,01 \%$ e 139,35 kg) do que no inverno (novembro a fevereiro) $(4,05 \%$ e $143,26 \mathrm{~kg})$.

Depeters e Cant (1992) e Depeters e Ferguson (1992), verificaram que altas temperaturas ambientais reduziam o conteúdo de proteína total e promoviam a diminuição de consistência de coágulo do leite proveniente de rebanhos submetidos a tais condições. Os autores citam ainda que a quantidade de proteína bruta do leite, proveniente de quatro raças leiteiras diferentes, foi menor no verão e maior no inverno. Allore et al (1997) evidenciaram diferenças na produção, composição e qualidade do leite de rebanhos com contagens de células somáticas inferiores a $500.000 \mathrm{cel} / \mathrm{ml}$ durante as estações do ano na região nordeste dos EUA, ressaltando que a área geográfica também produziu efeitos sobre a produção, composição e qualidade do leite.

Teixeira et al (2003) estudaram os efeitos do mês do ano, estágio de lactação, idade da vaca ao parto, época de parto e grupo racial sobre componentes do leite e contagem de células somáticas do leite de vacas da raça Holandesa no estado de Minas Gerais e constataram que a produção de leite aumentou da primeira para as outras lactações, porém as porcentagens de proteína e gordura do leite não variaram. Os efeitos do estágio de lactação e mês do ano sobre as porcentagens de gordura e proteína do leite foram significativos. Os autores ressaltaram também que flutuações sazonais das porcentagens de gordura e proteína seguiram tendências opostas à observada para produção de leite: maiores nos meses de inverno (época seca) e mais baixas nos meses de verão (época chuvosa).

Outro importante fator a ser considerado como possível determinante de alterações das características do leite, é o efeito raça. Coulon et al (1998), que estudou dados de trabalhos realizados no INRA (França) nos últimos 10 anos, afirmaram ser muito pequeno o efeito da raça sobre as características do leite principalmente com relação à composição protéica do leite, nas quais os autores demonstraram, que a freqüência gênica da variante $B$ no 
polimorfismo genético de kappa-caseína e beta-lactoglobulina, que seriam os principais responsáveis por aumentos na proporção de caseína em relação à proteína total do leite, têm freqüência muito baixa e diferem muito pouco entre diferentes raças. Por outro lado, Malossini et al (1996) e Bech e Kristiansen (1990), em trabalhos que avaliaram o efeito do polimorfismo genético sobre a composição protéica do leite, afirmaram ser maior a frequiência das variantes B para kappa-caseína e beta-lactoglobulina em animais da raça Jersey do que em animais da raça Holandesa.

\subsubsection{Estabilidade térmica do leite}

A estabilidade térmica do leite é caracterizada como o tempo necessário para o aparecimento de coagulação visível em determinado $\mathrm{pH}$ e temperatura, sendo esta a capacidade do leite em resistir à coagulação pelo calor, o que indica a sua aptidão para o processamento. Segundo Singh (2004), a estabilidade térmica do leite pode ser conceituada como sendo a sua capacidade de suportar a altas temperaturas de processamento sem apresentar coagulação ou gelatinização visíveis.

As principais variáveis que influenciam a estabilidade térmica do leite ou manutenção da estabilidade coloidal são: tempo, temperatura, $\mathrm{pH}$, equilíbrio salino, teor de uréia, estabilidade das micelas de caseína, período de lactação, manejo alimentar, e sanidade da glândula (SILVA e ALMEIDA, 1998; SINGH, 2004).

A habilidade do leite bovino em resistir a temperaturas relativamente altas de processamento é uma importante característica para indústria láctea (FOX e HOYNES, 1975).

Desta forma, é de grande importância determinar quais as reações que influenciam a velocidade de coagulação térmica do leite.

O método atualmente mais utilizado para se determinar à estabilidade térmica do leite é aquele, no qual amostras de leite são submetidas a provas de aquecimento controlado entre 
$130^{\circ} \mathrm{C}$ e $140^{\circ} \mathrm{C}$, até a observação de coagulação. O tempo de coagulação térmica do leite é aquele entre o aumento de temperatura das amostras até a observação da coagulação. Outros métodos utilizados para determinar estabilidade térmica incluem a prova de resistência ao álcool, sedimentação de proteína e determinação da viscosidade da amostra. Entretanto, as correlações entre os diferentes métodos são de forma geral insatisfatórias, e o tempo de estabilidade obtido nos diferentes testes não correspondem às características observadas, quando da esterilização comercial do leite (WOLFSCHOON-POMBO e LIMA, 1983; SINGH, 2004). Dentre as proteínas do leite, as soro-proteínas são as mais termolábeis e a ordem de instabilidade térmica inicia-se pelas imunoglobulinas, beta-lactoglobulina e por fim a alfalactoalbumina. O comportamento térmico das proteínas do soro é ditado, principalmente, pelas propriedades da beta-lactoglobulina que, por sua vez, são afetadas pelo pH do meio, lactose, teor de cloretos, íons de cálcio e outros (SINGH, 2004).

Os minerais contidos na alimentação animal não afetam de modo considerável a composição salina do leite. A deficiência de cálcio e fosfato na alimentação interfere de forma direta na produção em termos de quantidade, porém não afeta consideravelmente as concentrações dos componentes do leite. Alimentação com baixos teores de fibra pode diminuir o teor de citrato que é formado no ciclo de Krebs, ocasionando desequilíbrio salino, diminuindo assim a estabilidade térmica do leite (WOLFSCHOON-POMBO e LIMA, 1983; SINGH, 2004).

\subsubsection{Efeitos do aquecimento sobre a estabilidade}

A coagulação do leite em temperaturas altas, da ordem de $120^{\circ}$ a $140^{\circ} \mathrm{C}$, é conseqüência da perda da estabilidade térmica da micela de caseína, que resulta em uma série de alterações físico-químicas em seus componentes, e finalmente em coagulação (SINGH, 2004). As principais mudanças observadas após o aquecimento do leite são: 
a) Perda de gases, inclusive o dióxido de carbono, que pode ser observada em qualquer aumento de temperatura e depende em grande parte da pressão exercida no leite durante o aquecimento;

b) O deslocamento de parte do Ca e P solúvel para a fase coloidal do leite, que interfere no tamanho e propriedade das micelas de caseína;

c) Inativação de enzimas em temperatura superior a $50^{\circ} \mathrm{C}$;

d) Grande parte das proteínas do soro tem a sua solubilidade diminuída, como conseqüência de sua desnaturação térmica, sendo este fato relacionado com sua estrutura tridimensional compacta. Tais efeitos diferem em razão das sensibilidades específicas das soro-proteínas ao calor;

e) Formação de grupos sulfidrílicos acessíveis e também de pequenas quantidades de ácido sulfídrico a temperaturas maiores do que $60^{\circ} \mathrm{C}$;

f) Desnaturação da beta-lactoglobulina a $80^{\circ} \mathrm{C}$ e formação do complexo alfalactoglobulina/kappa-caseína, o qual é estabilizado a $90^{\circ} \mathrm{C}$.

g) Modificação da superfície micelar a $100^{\circ} \mathrm{C}$, comprometendo a estabilidade térmica do leite, por isso, recomenda-se que o pré-aquecimento para produtos UHT não deva ultrapassar $90^{\circ} \mathrm{C}$;

h) Decomposição da lactose formando ácidos orgânicos formando principalmente ácido fórmico e lático, tal reação é observada em temperaturas acima de $100^{\circ} \mathrm{C}$;

i) Início da agregação das micelas da caseína acima de $110^{\circ} \mathrm{C}$ e a estabilidade térmica tornase dependente do $\mathrm{pH}$;

j) Diminuição da estabilidade durante a estocagem, após tratamento térmico superior a $140^{\circ} \mathrm{C}$ devido a atividade de proteases termorresistentes e formação incompleta dos complexos estabilizadores do leite (WALSTRA e JENNESS, 1984). 


\subsubsection{Estabilidade ao álcool}

Os testes de estabilidade térmica do leite têm sido baseados em resultados de análises denominadas "teste de estabilidade ao etanol" ou "teste/prova do álcool", no qual o álcool etílico é adicionado ao leite em partes iguais (WHITE e DAVIES, 1958; IDF, 1969) ou provas de aquecimento.

O emprego do teste do álcool teve início na Europa como indicador de acidez excessiva, presença de colostro ou leite proveniente de animais com mastite. Por volta de 1980, estudos mostraram o valor do teste do álcool pela similaridade observada entre a instabilidade induzida pelo etanol e induzido pelo processamento térmico do leite (HORNE, 1992).

O princípio do teste do etanol baseia-se no mecanismo de desestabilização das caseínas por ação do etanol, o qual está vinculado ao efeito desnaturante do álcool, que promove a redução da constante dielétrica da mistura tornando-a um solvente desfavorável, podendo chegar a um limite crítico em que ocorra a desestabilização e precipitação. Alguns fatores são considerados como mais relevantes, como as cargas e as interações entre as micelas, pH, concentrações do álcool e composição do leite (HORNE, 1992).

Um dos principais alvos de estudos com relação ao teste do etanol, é determinar qual a graduação (v/v) de etanol deve ser aplicada ao teste para demonstrar a estabilidade térmica do leite. Shew (1981) sugeriu que para fins de processamento, o leite cru deve resistir pelo menos ao etanol $74 \%(\mathrm{v} / \mathrm{v})$. 


\subsection{Referências bibliográficas}

ALLORE, H.G., OLTENACU, P.A. e ERB, H.N. Effects of season, herd size, and geographic region on the composition and quality of milk in the northeast. Journal of Dairy Science, v.80, n.11, p.3040-3049. 1997.

BANKS, W., CLAPPERTON, J.L., GIRDLER, A.K., et al Effect of inclusion of different forms of dietary acid on the yield and composition of cow's milk. Journal Dairy Research, v.51, p.387-395. 1984.

BARGO, F., MULLER, L.D., DELAHOY, J.E., et al Milk response to concentrate supplementation of high producing dairy cows grazing at two pasture allowances. Journal of Dairy Science, v.85, n.7, p.1777-1792. 2002.

BOBE, G., FREEMAN, A.E., LINDBERG, G.L., et al The influence of milk protein phenotypes on fatty acid composition of milk from Holstein cows. Milchwissenschaft-Milk Science International, v.59, n.1-2, p.3-6. 2004.

BRODERICK, G.A. e CLAYTON, M.K. A statistical evaluation of animal and nutritional factors influencing concentrations of milk urea nitrogen. Journal of Dairy Science, v.80, n.11, p.2964-2971. 1997.

BRODERICK, G.A., CRAIG, W.M. e RICKER, D.B. Urea versus true protein as supplement for lactating dairy-cows fed grain plus mixtures of alfalfa and corn silages. Journal of Dairy Science, v.76, n.8, p.2266-2274. 1993.

BUTLER, J.A., WANDER, R.C., DU, S.H., et al Effects of selenium supplementation on milk selenium and fatty-acid levels in lactating women of low selenium status. Faseb Journal, v.9, n.3, p.159-159. 1995.

CARLSSON, J., BERGSTROM, J. e PEHRSON, B. Variations with breed, age, season, yield, stage of lactation and herd in the concentration of urea in bulk milk and in individual cows milk. Acta Veterinaria Scandinavica, v.36, n.2, p.245-254. 1995.

CARLSSON, J. e PEHRSON, B. The relationships between seasonal-variations in the concentration of urea in bulk milk and the production and fertility of dairy herds. Journal Of Veterinary Medicine Series A-Zentralblatt Fur Veterinarmedizin Reihe A-Physiology Pathology Clinical Medicine, v.40, n.3, p.205-212. 1993.

DEPETERS, E.J. e CANT, J.P. Nutritional factors influencing the nitrogen composition of bovine-milk - a review. Journal of Dairy Science, v.75, n.8, p.2043-2070. 1992.

DÜRR, J.W. Programa nacional de melhoria da qualidade do leite: Uma oportunidade única. O Compromisso com a qualidade do leite no Brasil, p.331. 2004.

FARRELL, H.M; JIMENEZ_FLORES, R; BLECK, G.T, BROWN, E.M; BUTLER, J.E; CREAMER, L.K; HICKS, C.L; HOLLAR, C.M; NG-KWAI-HANG, K.F; SWAISGOOD, H.E. Nomenclature of the proteins of cows'milk- sixth revision. Journal of Dairy Science, v.87, p. 1641-1674, 2004 
FARIA, F.J.C., GUIMARAES, S.E.F., MOURAO, G.B., et al Polimorphism analysis of betalactoglobulin gene on Nellore cows and effects on weaning weight of the calves. Arquivo Brasileiro De Medicina Veterinaria E Zootecnia, v.52, n.3, p.261-265. 2000.

FERNANDEZ, J.M., SAHLU, T., LU, C.D., et al Production and metabolic aspects of nonprotein nitrogen incorporation in lactation rations of dairy goats. Small Ruminant Research, v.26, n.1-2, p.105-117. 1997.

FONSECA, L.F.L. e SANTOS, M.V. Qualidade do leite e controle de mastite. São Paulo, SP: Lemos Editorial 2000. 176 p.

FOX, P.F. e HOYNES, M.C.T. Heat-stability of milk - influence of colloidal calciumphosphate and beta-lactoglobulin. Journal of Dairy Research, v.42, n.3, p.427-435. 1975.

FOX, P.F. e MC SWEENWEY, P.L.H. Dairy chemistry and biochemistry. p.478. 1998.

FOX, P.F. e MCSWEENEY, P.L.H. Proteolysis in cheese during ripening. Food Reviews International, v.12, n.4, p.457-509. 1996.

FREDEEN, A.H. Considerations in the nutritional modification of milk composition. Animal Feed Science and Technology, v.59, n.1-3, p.185-197. 1996.

GIELEN, M., DUFRASNE, I., LIMBOURG, P., et al Effect of grazing system, levels of concentrate and of nitrogen-fertilizer on urea concentration in milk and blood-plasma of dairy-cows. Annales de Medecine Veterinaire, v.133, n.7, p.589-598. 1989.

GRANT, R.J., COLENBRANDER, V.F. e MERTENS, D.R. Milk-fat depression in dairycows - role of particle-size of alfalfa hay. Journal of Dairy Science, v.73, n.7, p.1823-1833. 1990a.

GRANT, R.J., COLENBRANDER, V.F. e MERTENS, D.R. Milk-fat depression in dairycows - role of silage particle-size. Journal of Dairy Science, v.73, n.7, p.1834-1842. 1990b.

GUSTAFSSON, A.H. e PALMQUIST, D.L. Diurnal-variation of rumen ammonia, serum urea, and milk urea in dairy-cows at high and low yields. Journal of Dairy Science, v.76, n.2, p.475-484. 1993.

HAENLEIN, G.F.W., GONYON, D.S., MATHER, R.E., et al Associations of bovine blood and milk polymorphisms with lactation traits - Guernseys. Journal of Dairy Science, v.70, n.12, p.2599-2609. 1987.

HILL, A.R. Chemical-species in cheese and their origin in milk components. Abstracts of Papers of The American Chemical Society, v.206, p.26-AGFD. 1993.

HORNE, D.S. Ethanol stability. In: Fox, p. F. Advanced dairy chemistry, v.1, p.657-689. 1992.

INTERNATIONAL DAIRY FEDERATION Control methods for sterilized milk. n.48, p.3. 1969. 
JONKER, J.S., KOHN, R.A. e ERDMAN, R.A. Using milk urea nitrogen to predict nitrogen excretion and utilization efficiency in lactating dairy cows. Journal of Dairy Science, v.81, n.10, p.2681-2692. 1998.

JONKER, J.S., KOHN, R.A. e ERDMAN, R.A. Milk urea nitrogen target concentrations for lactating diary cows fed according to national research council recommendations. Journal of Dairy Science, v.82, n.6, p.1261-1273. 1999.

LANE, C.N., FOX, P.F., JOHNSTON, D.E., et al Contribution of coagulant to proteolysis and textural changes in cheddar cheese during ripening. International Dairy Journal, v.7, n.6-7, p.453-464. 1997.

LIN, C.Y., MCALLISTER, A.J., NGKWAIHANG, K.F., et al Effects of milk protein loci on 1st lactation production in dairy-cattle. Journal of Dairy Science, v.69, n.3, p.704-712. 1986.

MACKLE, T.R., BRYANT, A.M., PETCH, S.F., et al Nutritional influences on the composition of milk from cows of different protein phenotypes in New Zealand. Journal of Dairy Science, v.82, n.1, p.172-180. 1999.

MATOS, R.S., RORATO, P.R.N., G.B., F., et al Estudo dos efeitos genéticos e de meio ambiente sobre a produção de leite e gordura da raça holandês no estado do rio grande do sul. Ciência Rural, v.27, n.3, p.465-471. 1997.

MEDRANO, J.F. e AGUILARCORDOVA, E. Genotyping of bovine kappa-casein loci following DNA-sequence amplification. Bio-Technology, v.8, n.2, p.144-146. 1990.

MEYER, P.M., MACHADO, P.F., COLDEBELLA, A., et al Development of models to estimate milk urea nitrogen concentrations. Journal of Animal and Feed Sciences, v.13, p.527-530. 2004.

NAIKARE, B.D., KALE, K.M., JAGTAP, D.Z., et al Factors affecting fat percentage and total fat in gir crosses. Indian Journal of Animal Sciences, v.62, n.12, p.1209-1211. 1992.

NG-KWAI-HANG, K.F., MONARDES, H.G. e HAYES, J.F. Association between genetic polymorphism of milk proteins and production traits during three lactations. Journal of Dairy Science., v.73, n.12, p.3414-3420. 1990.

NOCEK, J.E. Bovine acidosis: Implications on laminitis. Journal of Dairy Science, v.80, n.5, p.1005-1028. 1997.

PERES, J.R. O leite como ferramenta do monitoramento nutricional In: GONZÁLEZ, f.D; DURR, J.W; FONTANELI, r.S. Uso do leite para monitorar a nutrição e o metabolismo de vacas leiteiras., p.30-45. 2001.

PIPEROVA, L.S., TETER, B.B., BRUCKENTAL, I., et al Mammary lipogenic enzyme activity, trans fatty acids and conjugated linoleic acids are altered in lactating dairy cows fed a milk fat-depressing diet. Journal of Nutrition, v.130, n.10, p.2568-2574. 2000. 
PONCE, P., CAPDEVILA, J. e LARANJA, L.F. Characterization of the abnormal milk syndrome: An approach of its probable causes and its corrections. Journal of Dairy Science, v.82, n.Supplement, 1, p.195. 1999.

RORATO, P.R.N., VAN VLECK, D., VERNEQUE, R.D., et al Genotype-environment interaction on milk production in Holstein herds in Brasil. 2. Use of an animal model. Revista Brasileira De Zootecnia-Brazilian Journal Of Animal Science, v.29, n.6, p.2030-2035. 2000.

ROSELER, D.K., FERGUSON, J.D., SNIFFEN, C.J., et al Dietary-protein degradability effects on plasma and milk urea nitrogen and milk nonprotein nitrogen in holstein cows. Journal of Dairy Science, v.76, n.2, p.525-534. 1993.

ROTHSCHILD, M.F. e SOLLER, M. Candidate gene analysis to detect genes controlling traits of economic importance in domestic livestock. International Symposium on Animal Breeding and Genetics, p.219-242. 1999.

SANTOS, F.A.P., HUBER, J.T., THEURER, C.B., et al Milk yield and composition of lactating cows fed steam-flaked sorghum and graded concentrations of ruminally degradable protein. Journal of Dairy Science, v.81, n.1, p.215-220. 1998.

SANTOS, F.L., LANA, R.D., SILVA, M.T.C., et al Milk production and composition in dairy cows receiving diets with different levels and sources of lipids supplementation. Revista Brasileira De Zootecnia-Brazilian Journal Of Animal Science, v.30, n.4, p.1376-1380. 2001a.

SANTOS, F.L., SILVA, M.T.C., LANA, R.D., et al Effect of lipids supplementation in the ration on production of conjugated linoleic acid (CLA) and milk fat composition of dairy cows. Revista Brasileira De Zootecnia-Brazilian Journal Of Animal Science, v.30, n.6, p.1931-1938. 2001b.

SHEW, D.I. Technical aspects of quality assurance. In: International dairy federation. New monograph on UHT milk., p.115-121. 1981.

SILVA, P.H.F. e ALMEIDA, M.C.F. Estabilidade térmica do leite. Revista do Instituto de Laticínios Cândido Tostes, v.53, n.304, p.157-163. 1998.

SINGH, H. Heat stability of milk. International Journal of Dairy Technology, v.57, n.2-3, p.111-119. 2004.

STEVANOVIC, M., STANOJCIC, S., DJUROVIC, J., et al Molecular marker technologies and selection for the traits of economic interest. Biotechnology in Animal Husbandry, v.16, n.1-2, p.25-34. 2000.

THEURER, C.B., HUBER, J.T., DELGADO-ELORDUY, A., et al Invited review: Summary of steam-flaking corn or sorghum grain for lactating dairy cows. Journal of Dairy Science, v.82, n.9, p.1950-1959. 1999.

VAN EENENNAAM, A. e MEDRANO, J.F. Milk protein polymorphisms in California dairy cattle. Journal of Dairy Science v.74, n.5, p.1730-1742. 1991a. 
VAN EENENNAAM, A.L. e MEDRANO, J.F. Differences in allelic protein expression in the milk of heterozygous kappa-casein cows. Journal of Dairy Science v.74, n.5, p.1491-1496. $1991 b$.

WALSTRA, P. e JENNESS, R. Proteins. In: (Ed.). Dairy chemistry and physics. New York, NY: John Wiley \& Sons, Inc., 1984. p.8-122.

WHITE, J.C.D. e DAVIES, D.T. The relation between the chemical composition of milk and the stability of the caseinate complex.4. Coagulation by heat. Journal of Dairy Research, v.25, n.2, p.281-296. 1958.

WOLFSCHOON-POMBO, A.F. e LIMA, A.F. Teor em uréia do leite fornecido no DPTA/ILCT. Revista do Instituto de Laticínios Cândido Tostes, v.38, n.226, p.19-22. 1983. 


\section{CAPÍTULO 2}

\section{Efeito da raça e sazonalidade sobre composição, características físico-químicas e estabilidade do leite ${ }^{1}$}

\section{Resumo}

Os objetivos do presente estudo foram de relacionar o efeito da raça, da estação do ano sobre as características físico-químicas (acidez, pH e crioscopia), composição (gordura, lactose, sólidos totais, contagem de células somáticas, uréia, proteína bruta, proteína verdadeira, nitrogênio não protéico e nitrogênio não caseinoso) e estabilidade do leite. Foram selecionados 11 rebanhos leiteiros comerciais, sendo cinco deles da raça Holandesa e seis da raça Girolanda, dos quais foram amostradas em média 122 vacas em lactação por rebanho, totalizando 1350 vacas amostradas em três períodos: 2 no período seco e 1 no período chuvoso. As vacas selecionadas foram analisadas quanto a composição e propriedades físicoquímicas do leite. Foi observado efeito da raça sobre acidez titulável, pH, lactose, uréia e estabilidade do leite; o efeito de sazonalidade mostrou-se significativo sobre $\mathrm{pH}$, crioscopia, lactose, uréia, PB, sólidos totais, CCS, PV, caseína, EqNNP, e estabilidade térmica do leite. Em animais da raça Girolanda, foram observados no período seco maiores teores de sólido totais. O ponto crioscópico do leite sofreu efeito do período de coleta somente em animais da raça Holandesa, onde valores mais altos foram observados durante o período seco. Os teores de lactose apresentaram maiores médias no período seco em animais da raça Holandesa. Os teores de uréia sofreram efeito de raça e período de coleta estudado. A PB do leite sofreu

\footnotetext{
${ }^{1}$ Projeto de pesquisa financiado pela Fundação de Amparo a Pesquisa do Estado de São Paulo - FAPESP Processo 02/12058-9.
} 
efeito dos fatores raça e período de coleta, onde animais da raça Holandesa e Girolanda apresentam maiores teores no período seco. A concentração de caseína do leite sofreu efeito significativo do período de coleta. A estabilidade térmica do leite sofreu influência da raça, o leite de animais da raça Holandesa mostrou-se mais estáveis do que os da raça Girolanda. A sazonalidade é um fator determinante para estabilidade do leite, pois o leite mostrou-se mais estável no período chuvoso que em período seco.

\section{Abstract}

The objectives of this study were to determine the effects of breed and season on physico-chemical properties (acidity, $\mathrm{pH}$ and cryoscopy), composition (fat, lactose, total solids, somatic cells count, urea, crude protein, true protein, non protein nitrogen and non casein nitrogen) and stability of milk. For this aim 11 dairy herds were selected, six of them composed of Girolando cows and five from Holstein cows, in average milk samples were taken of 112 cows from each herd for a total of 1350 cows, collected three times: twice in dry season and once on rainy season. Each cow were analyzed for milk composition and physicochemical properties. Breed effect was observed over acidity, $\mathrm{pH}$, lactose, urea and milk stability. Season effects was significant for $\mathrm{pH}$, cryoscopy, lactose, urea, $\mathrm{CP}$, total solids, SCC, TP, casein, EqNPN and heat milk stability. In cows Girolando it was observed highest total solids in dry season. Milk cryoscopy had season effects only on Holstein cows, with highest results in dry season. Lactose concentration was greatest in Holstein cow during dry season. Urea concentration showed breed and season effect on this study. Crude protein was affected by breed and season, in dry season the concentration were highest for Holstein and Girolanda. Casein milk concentration demonstrated season effect. Heat milk stability showed breed stability, milk from Holstein cow were more stable that milk from Girolanda cows. 
Season is a determinant factor for milk stability, milk showed more stable in rainy season than during dry period.

\subsection{Introdução}

O leite é um alimento altamente perecível, tendo suas características físicas, químicas e biológicas originais facilmente alteradas por uma série de mecanismos. Tais alterações podem ocorrer desde a fase de produção primária até a manipulação ao qual é submetido durante o processamento industrial (DÜRR, 2004).

Segundo Fox e Mc Sweenwey (1998), o leite é um fluido biológico extremamente variável e dependente de características nutricionais, raça, sazonalidade, sanidade, estágio de lactação, etc. O leite normalmente é composto por água $(87,3 \%)$ suspensão coloidal de pequenas partículas de proteína $(3,4 \%)$ ligadas a Ca e P; emulsão de glóbulos de gordura $(3,5 \%)$, vitaminas lipossolúveis, lactose $(4,8 \%)$, sais minerais $(0,8 \%)$ e vitaminas.

As características de produção são influenciadas direta e indiretamente pela temperatura, luminosidade e precipitação pluviométrica, conseqüentemente, em pastagens com qualidade diferenciada. A resposta fenotípica é modificada em função das diferenças encontradas no genótipo dos animais, no meio ambiente onde vivem e, ainda como consequiência da interação entre genótipo e ambiente (RORATO et al, 2000). Verdi et al, (1987) e Sargeant et al (1998) observaram, em seus estudos, efeitos da sazonalidade sobre a produção de leite e de seus componentes.

Banks et al (1984a) aponta que a gordura e a caseína apresentam tendências sazonais distintas de variação, fato este que leva a diferenças substanciais na produção de queijo durante $\mathrm{o}$ ano. Tais tendências resultam de fatores fisiológicos da própria lactação, disponibilidade e tipo de alimento, fatores ambientais, os quais têm implicações sobre o 
conteúdo de gordura e as relações proporcionais de caseína sobre o nitrogênio total (LACROIX et al, 1996).

Depeters e Cant (1992) e Depeters e Ferguson (1992), verificaram que altas temperaturas ambientais reduziam o conteúdo de proteína total e promoviam a diminuição de consistência de coágulo do leite proveniente de rebanhos submetidos a tal condição. Os autores citam ainda que a quantidade de proteína bruta do leite, proveniente de quatro raças leiteiras diferentes, foi menor no verão e maior no inverno. Allore et al (1997) evidenciaram diferenças na produção, composição e qualidade do leite de rebanhos com contagens de células somáticas inferiores a $500.000 \mathrm{cel} / \mathrm{ml}$ durante as estações do ano na região nordeste dos EUA, ressaltando que a área geográfica também produziu efeitos sobre a produção, composição e qualidade do leite.

Auldist et al (1998), buscando avaliar os efeitos ocasionados pela época do ano e o estágio da lactação dos animais na composição do leite de rebanhos da Nova Zelândia, verificaram que o fator de maior efeito sobre os componentes do leite de maior interesse industrial (proporções de caseína, proteínas do soro, nitrogênio caseinoso, nitrogênio total e proteína:gordura) foi a época do ano.

Teixeira et al (2003) estudaram os efeitos do mês do ano, estágio de lactação, idade da vaca ao parto, época de parto e grupo racial sobre componentes do leite e contagem de células somáticas do leite de vacas da raça Holandesa no estado de Minas Gerais e constataram que a produção de leite aumentou da primeira para as outras lactações, porém as porcentagens de proteína e gordura do leite não variaram. Os efeitos do estágio de lactação e mês do ano sobre as porcentagens de gordura e proteína do leite foram significativos. Os autores ressaltaram também que flutuações sazonais das porcentagens de gordura e proteína seguiram tendências opostas à observada para produção de leite: maiores nos meses de inverno (época seca) e mais baixas nos meses de verão (época chuvosa). 
Outro importante fator a ser considerado como possível determinante de alterações das características do leite é o efeito raça. Coulon et al (1998), que estudou dados de trabalhos realizados no INRA (França) nos últimos 10 anos, afirmaram ser muito pequeno o efeito da raça sobre as características do leite principalmente com relação à composição protéica do leite, onde os autores demonstraram que a freqüência gênica da variante B no polimorfismo genético de kappa-caseína e beta-lactoglobulina, que seriam os principais responsáveis por aumentos na proporção de caseína em relação à proteína total do leite, tem freqüência muito baixa e diferem muito pouco entre diferentes raças. Por outro lado, Malossini et al (1996) e Bech e Kristiansen (1990), em trabalhos que avaliaram o efeito do polimorfismo genético sobre a composição protéica do leite, afirmaram ser maior a frequiência das variantes B para kappa-caseína e beta-lactoglobulina em animais da raça Jersey do que em animais da raça Holandesa.

A estabilidade térmica do leite, outro importante critério para avaliação da qualidade do leite, é caracterizada como sendo o tempo necessário para originar coagulação ou gelatinização visível em determinado $\mathrm{pH}$ e temperatura. A capacidade do leite, serve para avaliar sua aptidão para o processamento industrial (SINGH, 2004). Com os avanços tecnológicos da indústria láctea, a habilidade do leite bovino resistir a temperaturas relativamente altas de processamento é uma das mais importantes características para indústria (HUPPERTZ et al, 2004; CRUDDEN et al, 2005). Desta forma, é de grande importância determinar quais fatores influenciam a velocidade de coagulação térmica do leite.

Por ser considerado um método rápido e de menor custo, a estabilidade térmica do leite tem sido estimada com base em resultados de análises denominadas "teste de estabilidade ao etanol" ou "teste/prova do álcool" onde o álcool etílico em uma determinada concentração é adicionado ao leite em partes iguais, observando a partir da homogeneização o comportamento da amostra de leite (WHITE e DAVIES, 1958b; IDF, 1969). 


\subsection{Objetivos}

O objetivo geral do presente estudo foi avaliar o efeito de raça e estação do ano sobre as características físico-químicas, composição e estabilidade do leite. Os objetivos específicos do presente estudo foram:

a) Avaliar o efeito da raça (Holandesa e Girolanda) sobre características físico-químicas (acidez, pH e crioscopia), composição (gordura, lactose, sólidos totais, CCS, uréia, PB, PV, NNP, NNC) e estabilidade do leite;

b) Determinar o efeito da estação do ano (seca e chuvosa) sobre características físicoquímicas (acidez, pH e crioscopia), composição (gordura, lactose, sólidos totais, CCS, uréia, PB, PV, NNP, NNC) e estabilidade do leite. 


\subsection{Material e métodos}

\subsubsection{Seleção dos rebanhos para coleta}

O presente experimento foi realizado, em sua fase de coletas de amostras, na região de Pirassununga-SP, onde foram selecionados 11 rebanhos leiteiros comerciais, entre os quais cinco contavam com animais da raça Holandesa e seis da raça Girolanda. Em média foram amostradas 122 vacas em lactação por rebanho, totalizando 1350 vacas amostradas em três períodos. Foram selecionados rebanhos leiteiros com adequado controle de dados, o que permitiu obtenção de informações relacionadas à produção, datas de parição, estágio de lactação e número lactações.

\subsubsection{Seleção das vacas}

Para a seleção das vacas amostradas foram utilizados os seguintes critérios: vacas de primeira, segunda ou terceira lactação; vacas entre $>30$ e <250 dias em lactação. Para as vacas da raça Girolanda, foram selecionados animais com graus de sangue entre 1/2, 3/4 e 3/8 Gir/Holandês. Foram excluídas as vacas com alterações visuais do leite detectáveis pelo teste de caneca de fundo escuro (mastite clínica) ou que tinham sido submetidas ao tratamento de mastite nas últimas duas semanas antes da coleta.

\subsubsection{Coleta de amostras de leite das vacas}

Foram coletadas três amostras individuais de leite das vacas em lactação dos rebanhos selecionados, nos seguintes períodos: coleta 1 (Setembro e Outubro de 2003: seco), coleta 2 (Junho e Julho de 2004: seco) e coleta 3 (Novembro e Dezembro de 2004: chuvoso). Adicionalmente, no momento da coleta foram registradas as seguintes informações de cada vaca leiteira selecionada: idade, dias em lactação, regime de alimentação a que o animal estava submetido (pasto, pasto com suplementação ou confinado). 
As amostras individuais de leite foram coletadas durante a ordenha da manhã, sendo representativa de toda a ordenha de cada animal. As amostras individuais foram coletadas em cada latão de ordenha nos sistemas denominados balde ao pé, a partir do balão de medição durante a ordenha ou pelo uso de dispositivos de medição por fluxo (tipo "True Type") e armazenadas em tubos plásticos previamente higienizados até a realização das análises. Para as análises físico-químicas do leite, as amostras foram resfriadas em recipientes térmicos com gelo em escamas até a realização das mesmas, em no máximo 6 horas. Para as análises de composição do leite, realizadas por absorção infravermelha e para CCS, as amostras foram enviadas para o Laboratório de Fisiologia da Lactação da ESALQ - USP (Clínica do Leite) em no máximo 72 horas. Para as demais análises, as amostras de leite foram congeladas $\left(-20^{\circ}\right.$ C) até a realização das mesmas.

\subsubsection{Delineamento experimental e análise estatística}

Foi utilizado o delineamento experimental tipo blocos ao acaso generalizados (GOMES, 1985), onde os blocos foram formados pelas fazendas, avaliando-se então o efeito da raça (Holandesa e Girolanda), da estação do ano (verão e inverno) sobre as variáveis resposta (características físico-químicas, composição e estabilidade do leite). Os dados foram analisados usando o PROC GLM do SAS. A análise de variância foi realizada considerandose os efeitos de raça nos animais amostrados e período do ano (seco ou chuvoso), além de suas interações. Os resultados de CCS (x 1000 céls/mL) foram transformados em escala logarítmica antes de ser submetidos à análise estatística. 


\subsubsection{Metodologias para análises}

\subsubsection{Determinação da composição do leite}

A composição do leite foi determinada no Laboratório de Fisiologia da Lactação da ESALQ - USP (Clínica do Leite), sendo as concentrações de gordura, lactose, sólidos totais analisados por absorção infravermelha, utilizando-se equipamento Bentley $2000^{\circledR}$ (BENTLEY, 1995a) e o nitrogênio uréico no leite $(\mathrm{mg} / \mathrm{dL})$, por método enzimático espectrofotométrico de trans-reflectância no equipamento ChemSpeck $150^{\circledR}$ (BENTLEY, 1998).

\subsubsection{Determinação das características físico-químicas do leite}

A determinação das características físico-químicas do leite - $\mathrm{pH}$, acidez titulável (Dornic), densidade e crioscopia foram realizadas de acordo com a metodologia descrita por Pereira et al, (2001).

\subsubsection{Determinação de estabilidade do leite}

A determinação da estabilidade do leite foi realizada pela prova de resistência ao álcool, onde partes iguais de leite e álcool foram misturados e homogeneizados por cinco vezes até a realização da interpretação do resultado, que variou entre leite sem coagulação (SC), coagulação fina (CF) e leite coagulado (C). A graduação alcoólica utilizada foi de $68^{\circ} \mathrm{GL}, 70^{\circ} \mathrm{GL}, 76^{\circ} \mathrm{GL}, 80^{\circ} \mathrm{GL}$ e $84^{\circ} \mathrm{GL}$ (WHITE e DAVIES, 1958a; IDF, 1969).

\subsubsection{Determinação do nitrogênio total (NT ou PB)}

A determinação da concentração de proteína do leite foi baseada na mensuração do NT pelo método de Kjeldahl, conforme metodologia descrita pela American Association Of Official Analytical Chemists (1995); método número 33.2.11; 991.20. O N foi então 
multiplicado pelo fator 6,38, para que os resultados fossem expressos em proteína bruta (PB) (BARBANO et al, 1990).

\subsubsection{Determinação do nitrogênio não-caseinoso (NNC)}

As frações de NNC e de caseína do leite foram determinadas no leite através de metodologia descrita por Lynch et al (1998). Resumidamente, a caseína do leite foi precipitada em $\mathrm{pH}=4,6$ usando-se solução de ácido acético e acetato de sódio. Após a precipitação, a caseína do leite foi separada por filtração e a concentração de $\mathrm{N}$ do filtrado (NNC) foi então determinada pelo método de Kjeldahl. Através da subtração da concentração de NT e NNC, foi determinada a concentração de caseína do leite.

\subsubsection{Determinação do nitrogênio não-protéico (NNP)}

As frações de NNP e de proteína verdadeira do leite foram determinadas no leite através de metodologia descrita por ( $\mathrm{LYNCH}$ et al, 1998). Resumidamente, a proteína verdadeira do leite é precipitada em pH ácido usando-se solução de ácido tricloracético. Após a precipitação, a proteína verdadeira do leite foi separada por filtração e a concentração de $\mathrm{N}$ do filtrado (NNP) foi então determinada pelo método de Kjeldahl. Através da subtração da concentração de NT e NNP, foi determinada a concentração de proteína verdadeira do leite.

\subsubsection{Contagem de células somáticas do leite}

As amostras de leite foram coletadas de forma composta, acondicionadas em frascos de plástico e conservadas em bromopol, sendo enviadas para o Laboratório Clínica do Leite Departamento de Produção Animal da ESALQ-USP (Piracicaba-SP), para a realização da contagem eletrônica de células somáticas $\left(\times 10^{3}\right.$ cels $\left./ \mathrm{mL}\right)$ por citometria de fluxo com equipamento Somacount $300^{\circledR}$ (BENTLEY, 1995b) 


\subsection{Resultados e discussão}

\subsubsection{Características físico-químicas e de composição.}

Os dados referentes ao efeito de raça e período de coleta, onde períodos de coleta compreenderam os meses de setembro e outubro de 2003 (seco), julho e agosto de 2004 (seco) e novembro e dezembro de 2004 (chuvoso), estão apresentados na tabela 1. Foi identificado efeito significativo do período de coleta sobre os resultados de $\mathrm{pH}(0,002)$, crioscopia $(P<0,001)$, lactose $(P<0,001)$ e CCS $(P<0,001)$ em rebanhos holandeses. Foi observado efeito significativo de período de coleta em animais da raça Girolanda apenas sobre os sólidos totais $(P=0,03)$, sendo que o leite coletado no período seco apresentou maiores valores $(11,90 \%)$ que os registrados no período chuvoso $(11,64 \%)$. Isto pode ser explicado, em parte, pelo fato dos animais da raça Holandesa serem mais sensíveis às variações climáticas entre os dois períodos de coleta avaliados. Com relação aos valores de $\mathrm{pH}$, foi observado efeito de raça sobre os valores, onde animais da raça holandesa apresentaram maiores médias para $\mathrm{pH}$, o que pode estar relacionado ao manejo nutricional mais equilibrado, a que estes animais são submetidos, além de melhores condições ambientais observadas durante a execução deste trabalho, efeito também de período de coleta foi observado nos animais da raça Holandesa onde as médias nos períodos chuvoso e seco (6,81 e 6,78, respectivamente). Marques (2003) obteve resultados muito próximos (6,74), em 501 amostras de leite proveniente de animais da raça Girolanda criadas no estado de São Paulo. Já Estrella (2001) avaliou 623 amostras de leite de animais da raça Holandesa e observou valores de pH de 6,40 em fase inicial de lactação (até 60 dias), e 6,69 após esta.

Quanto aos dados referentes ao ponto crioscópico do leite, observou-se efeito significativo $(P<0,001)$ do período de coleta em animais da raça Holandesa, cujos valores médios foram de $-0,537^{\circ} \mathrm{H}$ e $-0,542^{\circ} \mathrm{H}$, nos períodos chuvoso e seco, respectivamente. Além 
deste efeito, foi constatado efeito da interação entre raça e período de coleta $(P=0,025)$. Estes resultados estão dentro dos padrões mínimos exigidos pela legislação vigente (BRASIL, 2002 - IN 51) e próximos aos valores sugeridos por Pereira et al (2001). Na raça Girolanda, a crioscopia não apresentou diferença entre os períodos de coleta. Resultados estes são comparáveis aos de Lindmark-Månsson et al (2003), que ao analisarem a composição do leite de rebanhos suecos ao longo do ano observaram efeito da sazonalidade sobre o ponto crioscópico, sendo este menor no inverno que no verão, $-0,523^{\circ} \mathrm{H}$ e $-0,534^{\circ} \mathrm{H}$, respectivamente. Da mesma forma, Silva (2003) trabalhando com amostras de leite cru destinadas ao processamento UHT, observou ponto crioscópico mais baixo na estação seca do que na estação chuvosa do ano de 2002.

Os teores de gordura do leite foram semelhantes nas diferentes coletas para ambas as raças avaliadas, sendo os valores médios $(3,14 \%$ e $3,36 \%)$, os quais são inferiores aos encontrados por Walstra e Jenness (1984), que se referem ao teor médio de gordura do leite bovino como $3,9 \%$, com faixa de variação compreendida entre $2,4 \%$ e $5,5 \%$. O resultados médios de gordura do leite descritos no presente estudo concordam com os relatados por Silva (2003), que ao analisar amostras de leite destinados à fabricação de leite "UHT" nos estados de São Paulo, Rio Grande do Sul e Goiás, e, em estações secas e chuvosas, relatou não haver efeito significativo do período de coleta. Por outro lado, Auldist et al (1998), estudando a influência do estágio de lactação, assim como da sazonalidade sobre a composição do leite bovino em rebanhos da Nova Zelândia, observaram que a concentração de gordura foi modificada significativamente, havendo interação $(P<0,05)$ entre estágio de lactação e época do ano. Em estudo realizado por Ponce et al (1999), em mais de 800.000 amostras de leite cru em Cuba, foi descrito o teor médio de gordura igual a 3,73\% variando de 2,7\% a 5,9\%. Já, Machado et al (2003) ao analisar mais de 131.000 amostras de leite do sudeste de São Paulo, observou teor médio de gordura de 3,40\%, bem próximos aos encontrados neste experimento. 
A ausência de diferenças no percentual de gordura entre animais da raça Holandesa e Girolanda, durante o período seco e chuvoso, pode ser atribuída ao fato de que animais da raça Girolanda apresentam maiores teores médios de gordura, pode ser resultado do manejo alimentar ao qual tais animais eram submetidos. White et al (2001) em experimento que comparou ingestão de pasto mais concentrado com ingestão de dieta total, verificou menores teores de gordura do leite no sistema baseado em pastejo da ordem de 3,13\% contra 3,33\%.

Teixeira (2003) estudaram os efeitos do mês do ano, estágio de lactação, idade da vaca ao parto, época de parto e grupo racial sobre componentes do leite e contagem de células somáticas de vacas da raça Holandesa no estado de Minas Gerais e, constataram flutuações sazonais significativas dos teores de gordura e proteína. Os resultados indicaram tendências opostas à observada para produção de leite: maiores nos meses de inverno (época seca) e, mais baixas nos meses de verão (época chuvosa).

Os teores médios de lactose sofreram efeito significativo do período de coleta em animais da raça Holandesa, apresentando maiores médias no período seco (4,5\%) do que no chuvoso (4,37\%). Animais da raça Girolanda não apresentaram variação de teores de lactose em função do período de coleta. Destaca-se que houve interação entre os feitos de raça e período de coleta naquele estudo. Dados contrários foram observados por Silva (2003), que trabalhando com amostras de leite coletadas no estado de São Paulo, observou efeito significativo do período de coleta sobre o teor percentual de lactose do leite, relatando que os teores de lactose foram de $4,81 \%$ nas chuvas e $4,43 \%$ na estação seca do ano.

De acordo com Walstra e Jenness (1984), a variação percentual de lactose no leite situa-se entre $4,5 \%$ e $5 \%$, o que confirma os menores teores observados no presente estudo, principalmente no período chuvoso em animais da raça Holandesa. Em trabalhos que avaliaram mais de 800.000 amostras de leite em Cuba, Ponce et al (1999) observaram teor médio de lactose de $4,75 \%$ variando de $3,8 \%$ a $5,2 \%$. 
Banks et al (1984a) aponta que a gordura e a caseína apresentam tendências sazonais distintas de variação. Tais tendências, segundo Lacroix et al (1996) são resultado de fatores fisiológicos da própria lactação, disponibilidade e tipo de alimento, fatores ambientais e, todos têm implicações sobre o conteúdo de gordura.

Os resultados de sólidos totais não diferem entre si, quando consideramos a raça Holandesa, porém o mesmo não ocorre em animais da raça Girolanda, sendo significativo o efeito do período de coleta $(P=0,03)$, onde o teor de sólidos totais do leite foi maior $(11,90 \%)$ no período seco do que no período chuvoso $(11,64 \%)$. Estes resultados são comparáveis com os obtidos por RIBAS et al (2003a) e RIBAS et al (2003b), onde cerca de 36,4\% dos rebanhos avaliados na ocasião do estudo que avaliou 262.000 lactações entre 1998 e 2001, apresentaram sólidos totais abaixo de $12,1 \%$. 
Tabela 1 - Efeito de raça e período de coleta sobre a composição e características físico-químicas do leite.

\begin{tabular}{|c|c|c|c|c|c|c|c|c|c|c|c|c|c|c|}
\hline \multirow{2}{*}{$\begin{array}{c}\text { Raça } \\
\text { Período de coleta }\end{array}$} & \multicolumn{4}{|c|}{ Holandesa } & \multirow{2}{*}{$P$} & \multicolumn{4}{|c|}{ Girolanda } & \multirow{2}{*}{$P$} & \multicolumn{3}{|c|}{ Efeitos Principais } & \multirow{2}{*}{ EPM } \\
\hline & $\mathbf{N}$ & Chuva & $\mathbf{N}$ & Seca & & $\mathbf{n}$ & Chuva & $\mathbf{N}$ & Seca & & Raça & Período & Interação & \\
\hline Acidez $\left({ }^{\circ} \mathrm{D}\right)$ & 209 & 16,25 & 543 & 16,16 & NS & 130 & 16,77 & 427 & 16,89 & NS & $<0,001$ & NS & NS & 0,06 \\
\hline $\mathrm{pH}$ & 206 & 6,81 & 477 & 6,78 & 0,002 & 130 & 6,74 & 438 & 6,74 & NS & $<0,001$ & $<0,001$ & 0,026 & 0,0001 \\
\hline Crioscopia $\left({ }^{\circ} \mathrm{H}\right)$ & 195 & $-0,537$ & 511 & $-0,542$ & $<0,001$ & 116 & $-0,538$ & 417 & $-0,540$ & NS & NS & $<0,001$ & 0,025 & 0,0003 \\
\hline Gordura (\%) & 197 & 3,36 & 529 & 3,32 & NS & 125 & 3,14 & 424 & 3,23 & NS & NS & NS & NS & 0,02 \\
\hline Lactose $(\%)$ & 198 & 4,37 & 539 & 4,50 & $<0,001$ & 126 & 4,47 & 433 & 4,52 & NS & 0,01 & $<0,001$ & 0,007 & 0,007 \\
\hline Sólidos (\%) & 197 & 11,78 & 529 & 11,93 & NS & 125 & 11,64 & 429 & 11,90 & 0,03 & NS & 0,001 & NS & 0,03 \\
\hline CCS* & 209 & 5,48 & 562 & 5,28 & $<0,001$ & 130 & 5,42 & 449 & 5,37 & NS & NS & 0,015 & NS & 0,019 \\
\hline
\end{tabular}

EPM: erro padrão da média; NS: não significativo

* CCS expresso em Log CCS x1000 céls/mL 


\subsubsection{Composição protéica do leite}

Na tabela 2 são apresentados os resultados do efeito de raça e período de coleta, considerando-se que os períodos de coleta compreenderam os meses de setembro e outubro de 2003 (seco), julho e agosto de 2004 (seco) e novembro e dezembro de 2004 (chuvoso), sobre as características de composição protéica do leite. Foram observadas diferenças significativas sobre todos os parâmetros estudados (Uréia, PB, EqNNP, PV, caseína e EqNNC) em relação à raça e período de coleta da amostra. Os maiores teores de PB e PV foram observados em ambas as raças no período seco, fato que pode ser atribuído ao fato de que nesta estação é comum o emprego de concentrado e suplementação com silagem aos animais levando a um incremento dos teores notados no período seco em relação ao chuvoso. Observação, esta, feita de forma semelhante por Silva (2003) e Estrella (2001). Outro ponto a ser levado em conta, principalmente em animais da raça Holandesa, são as temperaturas médias mais brandas durante o período seco, o que diminui de forma considerável o estresse térmico a que os animais são submetidos, o que favorece melhor qualidade alimentação e conseqüente incremento na composição láctea.

A concentração de uréia sofreu efeito significativo de raça e período de coleta estudado, porém divergem entre si, visto que em rebanhos Holandeses o teor de uréia foi maior no período chuvoso $(20,89 \mathrm{mg} / \mathrm{dL})$ do que no período seco $(16,12 \mathrm{mg} / \mathrm{dL})$, já nos animais da raça Girolanda observou-se o inverso, ou seja, teores de uréia foram maiores na seca $(15,69 \mathrm{mg} / \mathrm{dL})$ do que no período chuvoso. Estes dados podem ser atribuídos ao fato dos animais da raça Girolanda são normalmente submetidos a dietas com baixas quantidades de carboidratos e concentrados à base de uréia e sulfato de amônia, levando assim ao aumento nos níveis de NUP e NUL. Fernandez et al (1997), observaram mudanças na fração nitrogenada do leite, comprometendo suas propriedades de processamento quando do uso de altos teores de NNP (50\% da PB) na dieta dos animais. Broderick et al (1993) observaram 
diferenças nos teores de proteína e gordura do leite quando da comparação de dietas com PV ou uréia em dietas com silagens de alfafa e milho. Dados estes que discordam de Bargo et al (2002), no qual os animais alimentados em sistema confinado com ração total tiveram menores teores de uréia $(10,6 \mathrm{mg} / \mathrm{dL}$ vs. $14,9 \mathrm{mg} / \mathrm{dL})$ do que em sistemas de pastejo, mostrando ser significativo o efeito de sistema de alimentação $(P<0,05)$. Os valores observados no presente estudo encontram-se acima dos descritos por Machado et al (2003), que avaliando 90.000 animais ao todo, verificou teores médios em $2001 \mathrm{de} 11,18 \mathrm{mg} / \mathrm{dL}, 2002 \mathrm{de}$ 9,60mg/dL e $20038,40 \mathrm{mg} / \mathrm{dL}$.

O teor de PB do leite sofreu efeito significativo dos fatores raça e período de coleta, apresentando comportamento diferente dos teores de uréia, onde animais da raça Holandesa e Girolanda apresentaram maiores teores de PB no período seco $(3,16 \%$ e $3,15 \%)$ do que no período chuvoso $(3,0 \%$ e $3,01 \%)$. Estes dados concordam com os descritos por Depeters e Cant (1992) e Depeters e Ferguson (1992), que verificaram que altas temperaturas ambientais reduziam o conteúdo de proteína total e promoviam a diminuição de consistência de coágulo do leite proveniente de rebanhos submetidos a tal condição. Os autores citam ainda que a quantidade de proteína bruta do leite, proveniente de quatro raças leiteiras diferentes, foi menor no verão e maior no inverno. Os teores encontrados estão abaixo dos teores considerados normais (3,5\%) por Fox e Mc Sweenwey (1998), porém próximos aos descritos por Ribas et al (2003a) e Ribas et al (2003b) que avaliaram mais de 262.000 lactações e encontraram teores de PB de 3,24\%. Auldist et al (1998) ao compararem vacas em restrição alimentar com vacas em pastejo, observaram que o segundo grupo apresentava maior produção de leite, assim como teor de PB (3,32\% vs. 3,02\%) e caseína (2,68\% vs. 2,76\%). Lindmark-Månsson et al (2003), por sua vez, não observaram efeito da sazonalidade $(P<0,001)$ sobre a composição protéica do leite. 
Auldist et al (1998), estudando a influência do estágio de lactação, assim como a sazonalidade sobre a composição do leite bovino em rebanhos da Nova Zelândia, observaram que o teor de proteína bruta não sofreu efeito da interação entre estágio de lactação e sazonalidade, entretanto foram observados efeitos individuais sobre cada um dos fatores $(P<0,01)$. Auldist et al (1998), buscando avaliar os efeitos ocasionados pela época do ano e o estágio da lactação sobre a composição do leite de rebanhos da Nova Zelândia, verificaram que o fator de maior efeito sobre os componentes do leite (proporções de caseína:proteínas do soro, nitrogênio caseinoso:nitrogênio total e proteína:gordura) foi a época do ano.

Lacroix et al (1996), objetivando determinar as variações regionais e sazonais sobre as frações de nitrogênio e seus efeitos na relação caseína:proteína total e proteína verdadeira, no Canadá, encontraram diferenças significativas nas frações de nitrogênio tanto entre as regiões consideradas, quanto em situações sazonais diferentes. De acordo com os autores, os efeitos sazonais foram as maiores fontes de variação (10 vezes maior que os efeitos regionais observados). Por outro lado Depeters e Cant (1992), comparando o leite de vacas submetidas ao sistema de pastagem ad libitum com ingestão restrita, observaram que o primeiro sistema proporcionou um acréscimo de conteúdo protéico e de produção $(3,73 \% ; 0,69 \mathrm{~kg} / \mathrm{d})$ quando comparado ao de animais submetidos à ingestão restrita $(3,61 \% ; 0,47 \mathrm{~kg} / \mathrm{d})$. Banks et al (1984b), com o mesmo tipo de experimento, observou aumento do conteúdo protéico e de produção de leite. O aumento também foi observado com a alteração da relação forragem:concentrado, embora o conteúdo caseinoso seja uma característica de difícil manipulação através da dieta. Os teores médios de caseína descritos no presente estudo sofreram efeito de período de coleta, onde animais da raça Holandesa e Girolanda apresentaram maiores teores no período seco $(2,39 \% 32,37 \%$, respectivamente) que em período chuvoso $(2,25 \%$ e 2,26$)$, valores estes considerados abaixo do normal $(2,80 \%)$ por Fox e Mc Sweenwey (1998) 
Os teores de caseína sofreram efeito significativo do período de coleta, mas não teve diferença entre as raças estudadas. Os animais da raça Holandesa e Girolanda apresentaram teores maiores de caseína no período seco $(2,39 \%$ e $2,37 \%)$ do que no chuvoso $(2,25 \%$ e 2,26\%). Estes dados estão de acordo com Coulon et al (1998), que, na França, ao analisarem dados de mais de 900 animais por mais de 10 anos, verificaram não haver influência da raça sobre teores de caseína. Isto pode ser justificado pelo fato de que a freqüência gênica do alelo B no polimorfismo de genes relacionados à secreção de proteína e que proporciona maiores teores de caseína no leite não tem alta prevalência, mesmo quando comparadas diferentes raças. Os teores de PV sofreram efeito altamente significativo do fator período de coleta, apresentando teores maiores no período seco $(2,94 \%)$ do que no período chuvoso $(2,78 \%)$, dados que acompanham a variação dos teores de PB e uréia. 
Tabela 2 - Efeito de raça e período de coleta sobre composição protéica do leite.

\begin{tabular}{|c|c|c|c|c|c|c|c|c|c|c|c|c|c|c|}
\hline \multirow{2}{*}{$\begin{array}{l}\text { Raça } \\
\text { Período de coleta }\end{array}$} & \multicolumn{4}{|c|}{ Holandesa } & \multirow{2}{*}{$\boldsymbol{P}$} & \multicolumn{4}{|c|}{ Girolanda } & \multirow{2}{*}{$P$} & \multicolumn{3}{|c|}{ Efeitos Principais } & \multirow{2}{*}{ EPM } \\
\hline & $\mathbf{N}$ & Chuva & $\mathbf{N}$ & Seca & & $\mathbf{n}$ & Chuva & $\mathbf{n}$ & Seca & & Raça & Período & Interação & \\
\hline Uréia (mg/dL) & 198 & 20,89 & 560 & 16,12 & $<0,001$ & 117 & 13,57 & 429 & 15,69 & 0,01 & $<0,001$ & $<0,001$ & $<0,001$ & 0,13 \\
\hline PB $(\%)$ & 205 & 3,00 & 528 & 3,16 & $<0,001$ & 126 & 3,01 & 423 & 3,15 & $<0,001$ & NS & $<0,001$ & NS & 0,008 \\
\hline EqNNP $(\%)$ & 188 & 0,25 & 560 & 0,23 & $<0,001$ & 116 & 0,26 & 447 & 0,21 & $<0,001$ & NS & $<0,001$ & $<0,001$ & 0,001 \\
\hline PV (\%) & 204 & 2,78 & 527 & 2,94 & $<0,001$ & 125 & 2,78 & 423 & 2,94 & $<0,001$ & NS & $<0,001$ & NS & 0,007 \\
\hline Caseína (\%) & 204 & 2,25 & 527 & 2,39 & $<0,001$ & 125 & 2,26 & 423 & 2,37 & $<0,001$ & NS & $<0,001$ & NS & 0,0007 \\
\hline EqNNC (\%) & 204 & 0,75 & 527 & 0,77 & $<0,001$ & 125 & 0,75 & 423 & 0,78 & 0,007 & NS & 0,041 & NS & 0,0046 \\
\hline
\end{tabular}

EPM: erro padrão da média; NS: não significativo 


\subsubsection{Estabilidade do leite}

A estabilidade do leite de amostras individuais foi analisada no presente estudo pela prova de resistência ao álcool. Na tabela 3 são apresentados os resultados do efeito de raça sobre a estabilidade do leite.

Tabela 3 - Efeito da raça sobre a estabilidade do leite.

\begin{tabular}{|c|c|c|c|}
\hline \multirow{2}{*}{ Raça } & \multicolumn{3}{|c|}{ PROVA DO ALCOOL } \\
\hline & $\mathrm{NC}^{*}(\%)$ & $\mathrm{C}^{* *}\left({ }^{\circ} \mathrm{GL}\right)$ & DP \\
\hline Girolanda & 49,05 & 78,5 & 5,0 \\
\hline Holandês & 21,04 & 80,0 & 4,8 \\
\hline TOTAL & 66,94 & 80,6 & 4,8 \\
\hline$P$ & & 0,003 & \\
\hline
\end{tabular}

Observou-se efeito significativo de raça sobre a estabilidade do leite $(P<, 003)$ para as amostras que apresentaram coagulação visível, sendo que a raça Holandesa $\left(80,6^{\circ} \mathrm{GL}\right)$ apresentou leite com maior resistência à prova do álcool do que a raça Girolanda $\left(78,5^{\circ} \mathrm{GL}\right)$. Ikonen et al (2004) que avaliou efeitos genéticos sobre as propriedades de coagulação do leite em mais de 4.600 amostras, concluiu haver efeito altamente significativo do genótipo sobre a estabilidade e propriedades do leite. Segundo Shew (1981), o leite deve resistir, no mínimo, ao etanol $74^{\circ} \mathrm{GL}$ para ser considerado ideal para processamento, o qual, se aplicado aos resultados apresentados nos levaria a concluir que todas as amostras de leite seriam aptas para processamento.

$\mathrm{Na}$ tabela 4 são apresentados os resultados do efeito de período de coleta sobre a estabilidade do leite. 
Tabela 4 - Efeito do período de coleta sobre a estabilidade do leite

\begin{tabular}{llll}
\hline \multirow{2}{*}{ Período } & \multicolumn{3}{c}{ PROVA DO ALCOOL } \\
\cline { 2 - 4 } & $\mathbf{N C} *(\%)$ & $\mathbf{C} * *(\mathbf{G L})$ & DP \\
\hline Chuvoso & 22,12 & 80,93 & 4,38 \\
Seco & 36,73 & 78,68 & 5,02 \\
\hline TOTAL & 66,94 & 65,54 & 4,83 \\
\hline$P$ & \multicolumn{3}{c}{$<0,001$} \\
\hline \multicolumn{3}{c}{$*$ NC - amostras que não apresentaram coagulação } \\
\end{tabular}

Conforme apresentado na tabela 4 , foi observado efeito do período de coleta sobre a estabilidade do leite $(P<0,001)$, onde o período seco $\left(78,68^{\circ} \mathrm{GL}\right)$ apresentou menor estabilidade em relação ao período chuvoso $\left(80,93^{\circ} \mathrm{GL}\right)$. Dados estes que concordam com os observados por Silva (2003), que observou maior estabilidade do leite para a prova do álcool na estação chuvosa nos estados de São Paulo e Goiás, o mesmo não acontecendo no leite proveniente do estado do Rio Grande do Sul. Este fato pode ser explicado pelo fato de que as amostras de São Paulo e Goiás apresentaram, no mesmo experimento, maiores teores de citrato do que o leite do Rio Grande do Sul, e este por sua vez, segundo Singh (2004) confere ao leite maior estabilidade ao leite devido ao efeito seqüestrante do cálcio iônico. 


\subsection{Conclusão}

De acordo com os resultados obtidos no presente estudo, podem ser enumeradas as seguintes conclusões:

a) Em animais da raça Girolanda observou-se maiores teores de sólido totais no período seco em comparação com o período chuvoso;

b) Os valores de $\mathrm{pH}$ em vacas da raça Holandesa são maiores do que em animais da raça Girolanda, e quando comparados os dois períodos do ano (seco e chuvoso) animais da raça Holandesa apresentam maior pH no período chuvoso. Em animais da raça Girolanda não se observa diferença entre os valores de $\mathrm{pH}$ ao longo do ano;

c) O ponto crioscópico do leite sofre efeito do período do ano somente em animais da raça Holandesa, cujos maiores valores são observados durante o período seco;

d) Os teores de lactose sofrem variação em relação ao período do ano em vacas da raça Holandesa, apresentando maiores médias no período seco do que no chuvoso;

e) Os teores de uréia variaram em função de raça e período do ano, sendo que em rebanhos Holandeses o teor de uréia é maior no período chuvoso do que no período seco, e nas vacas da raça Girolanda observa-se o inverso;

f) A PB do leite varia em função da raça e período do ano, sendo que animais da raça Holandesa e Girolanda apresentam maiores teores no período seco;

g) A concentração de caseína do leite sofre efeito significativo do período do ano e raça, sendo maior no período seco para ambas as raças;

h) A estabilidade térmica do leite sofre influência da raça, sendo que o leite proveniente de animais da raça Holandesa é mais estável do que em animais da raça Girolanda; 
i) Sazonalidade é um fator determinante para estabilidade do leite, pois o leite mostra-se mais estável no período chuvoso que em período seco. 


\subsection{Referências bibliográficas}

ALLORE, H.G., OLTENACU, P.A. e ERB, H.N. Effects of season, herd size, and geographic region on the composition and quality of milk in the northeast. Journal of Dairy Science, v.80, n.11, p.3040-3049. 1997.

\section{AMERICAN ASSOCIATION OF OFFICIAL ANALYTICAL CHEMISTS. Official methods of analysis. Arlington, VA. 1995}

AULDIST, M.J., WALSH, B.J. e THOMSON, N.A. Seasonal and lactational influences ion bovine milk composition in New Zealand. Journal of Dairy Research, v.65, n.3, p.401-411. 1998.

BANKS, J.M., MUIR, D.D. e TAMINE, A.T. A comparison of the quality of cheddar cheese prodced from seasonal and standardized milk. Journal Society Dairy Technology, v.37, n.88. 1984a.

BANKS, W., CLAPPERTON, J.L., GIRDLER, A.K., et al Effect of inclusion of different forms of dietary acid on the yield and composition of cow's milk. Journal Dairy Research, v.51, p.387-395. 1984b.

BARBANO, D.M., CLARK, J.L., DUNHAM, C.E., et al Kjeldahl method for determination of total nitrogen-content of milk - collaborative study. Journal of The Association of Official Analytical Chemists, v.73, n.6, p.849-859. 1990.

BARGO, F., MULLER, L.D., DELAHOY, J.E., et al Milk response to concentrate supplementation of high producing dairy cows grazing at two pasture allowances. Journal of Dairy Science, v.85, n.7, p.1777-1792. 2002.

BECH, A.M. e KRISTIANSEN, K.R. Milk protein polymorphism in Danish dairy-cattle and the influence of genetic-variants on milk-yield. Journal of Dairy Research, v.57, n.1, p.53-62. 1990.

BENTLEY. Bentley 2000: Operator's manual p.77. 1995a.

BENTLEY. Somacount 300: Operator's manual p.12. 1995b.

BENTLEY. Chemspeck 150:User's guide. p.17. 1998.

BRASIL. Instrução Normativa 51, de 20 se setembro de 2002. Aprova os regulamentos técnicos de produção, identidade, qualidade, coleta e transporte de leite. Diário Oficial da União, n.1, p.13-21. 2002.

BRODERICK, G.A., CRAIG, W.M. e RICKER, D.B. Urea versus true protein as supplement for lactating dairy-cows fed grain plus mixtures of alfalfa and corn silages. Journal of Dairy Science, v.76, n.8, p.2266-2274. 1993. 
COULON, J.B., HURTAUD, C., REMOND, B., et al Factors contributing to variation in the proportion of casein in cows' milk true protein. Productions Animales, v.11, n.4, p.299-310. 1998.

CRUDDEN, A., AFOUFA-BASTIEN, D., FOX, P.F., et al Effect of hydrolysis of casein by plasmin on the heat stability of milk. International Dairy Journal, v.15, n.10, p.1017-1025. 2005.

DEPETERS, E.J. e CANT, J.P. Nutritional factors influencing the nitrogen composition of bovine-milk - a review. Journal of Dairy Science, v.75, n.8, p.2043-2070. 1992.

DEPETERS, E.J. e FERGUSON, J.D. Nonprotein nitrogen and protein distribution in the milk of cows. Journal of Dairy Science, v.75, n.11, p.3192-3209. 1992.

DÜRR, J.W. Programa nacional de melhoria da qualidade do leite: Uma oportunidade única. $\mathbf{O}$ Compromisso com a qualidade do leite no Brasil, p.331. 2004.

ESTRELLA, S.L.G. Características físico-químicas e celulares do leite de bovinos da raça holandesa, criados no estado de São Paulo: Influência da fase de lactação dos quartos mamários, do número de lactações e do isolamento bacteriano. 2001.

FERNANDEZ, J.M., SAHLU, T., LU, C.D., et al Production and metabolic aspects of nonprotein nitrogen incorporation in lactation rations of dairy goats. Small Ruminant Research, v.26, n.1-2, p.105-117. 1997.

FOX, P.F. e MC SWEENWEY, P.L.H. Dairy chemistry and biochemistry. p.478. 1998.

GOMES, P. Curso de estatística experimental. p.467. 1985.

PIMENTEL GOMES, F. Curso de Estatística Experimental. ESALQ, Piracicaba, SP, 467 p, 1985.

HUPPERTZ, T., GROSMAN, S., FOX, P.F., et al Heat and ethanol stabilities of high-pressuretreated bovine milk. International Dairy Journal, v.14, n.2, p.125-133. 2004.

IDF. Control methods for sterilized milk. n.48, p.3. 1969.

IKONEN, T., MORRI, S., TYRISEVA, A.M., et al Genetic and phenotypic correlations between milk coagulation properties, milk production traits, somatic cell count, casein content, and ph of milk. Journal of Dairy Science, v.87, n.2, p.458-467. 2004.

LACROIX, C., VERRET, P. e PAQUIN, P. Regional and seasonal variations of nitrogen fractions in commingled milk. International Dairy Journal, v.6, n.10, p.947. 1996.

LINDMARK-MÅNSSON, H., FONDEN, R. e PETTERSSON, H. Composition of Swedish dairy milk. International Dairy Journal, v.13, n.6, p.409. 2003. 
LYNCH, J.M., BARBANO, D.M. e FLEMING, J.R. Indirect and direct determination of the casein content of milk by Kjeldahl nitrogen analysis: Collaborative study. Journal of AOAC International, v.81, n.4, p.763-774. 1998.

MACHADO, P.F., CASSOLI, L.D., COLDEBELLA, A., et al Panorama da qualidade do leite na região sudeste - São Paulo. Diagnostico da qualidade do leite, impacto para a industria e a questão dos resíduos de antibióticos., p.39-45. 2003.

MALOSSINI, F., BOVOLENTA, S., PIRAS, C., et al Effect of diet and breed on milk composition and rennet coagulation properties. Annales De Zootechnie, v.45, n.1, p.29-40. 1996.

MARQUES, R.S. Características físico-químicas e celulares do leite de bovinos da raça girolanda criados no estado de são paulo. 2003.

PEREIRA, D.B.C.P., SILVA, P.H.F., COSTA JR, L.C.G., et al Físico-química do leite e derivados - métodos analíticos. Juiz de Fora-MG: EPAMIG. 2001. 234 p.

PONCE, P., CAPDEVILA, J. e LARANJA, L.F. Characterization of the abnormal milk syndrome: An approach of its probable causes and its corrections. Journal of Dairy Science, v.82, n.Supplement, 1, p.195. 1999.

RIBAS, N.P., HARTMAN, W., PEREZ JR, F., et al Sólidos totais em amostras de leite de tanques do estado de Santa Catarina, Paraná e São Paulo. Diagnostico da qualidade do leite, impacto para a industria e a questão dos resíduos de antibióticos., p.19-25. 2003a.

RIBAS, N.P., PAULA, M.C. e ANDRADE, U.V.C. Contagem e escore de células somáticas em amostras de leite de tanques nos estados de Santa Catarina, Paraná e São Paulo. Diagnostico da qualidade do leite, impacto para a industria e a questão dos resíduos de antibióticos., p.2638. $2003 \mathrm{~b}$.

RORATO, P.R.N., VAN VLECK, D., VERNEQUE, R.D., et al Genotype-environment interaction on milk production in Holstein herds in Brasil. 2. Use of an animal model. Revista Brasileira De Zootecnia-Brazilian Journal Of Animal Science, v.29, n.6, p.2030-2035. 2000.

SARGEANT, J.M., MARTIN, S.W., LISSEMORE, K.D., et al Associations between individual cow factors and milk-protein production. Preventive Veterinary Medicine, v.34, n.1, p.57-72. 1998.

SHEW, D.I. Technical aspects of quality assurance. In: International dairy federation. New monograph on UHT milk., p.115-121. 1981.

SILVA, P.H.F. Leite uht: Fatores determinantes para sedimentação e gelificação. p.162. 2003.

SINGH, H. Heat stability of milk. International Journal of Dairy Technology, v.57, n.2-3, p.111-119. 2004. 
TEIXEIRA, N.M., FREITAS, A.F BARRA, R.B. Environmental factors influencing monthly variation of milk composition and somatic cell counts in herds of the state of minas gerais. Arquivo Brasileiro de Medicina Veterinária e Zootecnia. 2003.

VERDI, R.J., BARBANO, D.M., DELLAVALLE, M.E., et al Variability in true protein, casein, nonprotein nitrogen, and proteolysis in high and low somatic cell milks. Journal of Dairy Science, v.70, n.2, p.230-42. 1987.

WALSTRA, P. e JENNESS, R. Proteins. In: (Ed.). Dairy chemistry and physics. New York, NY: John Wiley \& Sons, Inc., 1984. p.8-122.

WHITE, J.C.D. e DAVIES, D.T. The relation between the chemical composition of milk and the stability of the caseinate complex.1. General introduction, description of samples, methods and chemical composition of samples. Journal of Dairy Research, v.25, n.2, p.236-255. 1958a.

WHITE, J.C.D. e DAVIES, D.T. The relation between the chemical composition of milk and the stability of the caseinate complex.4. Coagulation by heat. Journal of Dairy Research, v.25, n.2, p.281-296. $1958 b$.

WHITE, S.L., BERTRAND, J.A., WADE, M.R., et al Comparison of fatty acid content of milk from jersey and Holstein cows consuming pasture or a total mixed ration. Journal of Dairy Science, v.84, n.10, p.2295-2301. 2001. 


\section{CAPÍTULO 3}

\section{Polimorfismo da kappa-caseína de vacas leiteiras e características físico-químicas, composição e estabilidade térmica do leite}

\section{Resumo}

Os objetivos do presente estudo foram os de relacionar o efeito do polimorfismo genético da kappa-caseína, sobre as características físico-químicas (acidez, pH e crioscopia), composição (gordura, lactose, sólidos totais, contagem de células somáticas, uréia, proteína bruta, proteína verdadeira, nitrogênio não protéico e nitrogênio não caseinoso) e estabilidade do leite. Foram selecionados 11 rebanhos leiteiros comerciais, sendo cinco deles da raça Holandesa e seis da raça Girolanda, dos quais foram amostradas em média 122 vacas em lactação por rebanho, totalizando 1350 vacas amostradas em três períodos: 2 no período seco e 1 no período chuvoso. As vacas selecionadas foram analisadas quanto à composição e propriedades físico-químicas do leite, assim como para a determinação do polimorfismo de kappa-caseína, as quais submetidas à amplificação por reação em cadeia de polimerase para a identificação de genes $\mathrm{AA}, \mathrm{AB}$ e $\mathrm{BB}$ para kappa-caseína. A freqüência do alelo A foi maior em ambas as raças e o efeito do polimorfismo genético de kappa-caseína não foi observado sobre nenhuma das características físico-químicas (acidez, pH e crioscopia), composição (gordura, lactose, sólidos totais, contagem de células somáticas, uréia, proteína bruta, proteína verdadeira, nitrogênio não protéico e nitrogênio não caseinoso) e estabilidade do leite. 


\begin{abstract}
The aim of this study were to determine the effects of kappa-casein gene polymorphisms on physico-chemical properties (acidity, $\mathrm{pH}$ and cryoscopy), composition (fat, lactose, total solids, somatic cells count, urea, crude protein, true protein, non protein nitrogen and non casein nitrogen) and stability of milk. For this aim 11 dairy herds were selected, six of them composed of Girolando cows and five from Holstein cows, in average milk samples were taken of 112 cows from each herd for a total of 1350 cows, collected three times: twice in dry season and once on rainy season. Each cow were analyzed for milk composition, physico-chemical properties, and to determine its kappa-casein polymorphism with chain polymerase reaction to detect $\mathrm{AA}, \mathrm{AB}$ and BB polimorphism. Kappa-casein allele A had a higher frequency in both, Girolando and Holstein cows. No effect of kappa-casein polymorphism was observed on milk physico-chemical characteristics (acidity, $\mathrm{pH}$ and cryoscopy), milk composition (fat, total solids, lactose, SCC, and milk urea), milk protein composition (EqNPN, NCNC, TP, casein and EqNCN) and milk alcohol stability.
\end{abstract}

\title{
3.1 Introdução
}

Nos últimos anos o avanço da biologia molecular trouxe a possibilidade da prática da seleção artificial baseada em avaliações genéticas que predizem o mérito genético aditivo do animal para determinada característica (MOODY et al, 1994). A identificação de polimorfismos em vários sítios genômicos nos animais é possível graças ao uso da reação em cadeia de polimerase (PCR-polymerase chain reaction).

A maioria das características de importância econômica em bovinos, resulta da ação conjunta de genes e ambiente, e são denominadas poligênicas, quantitativas ou de múltipla 
herança. O fenótipo resultante apresenta variação contínua ao invés de classes fenotípicas discretas. Caracteres de produção, qualidade, precocidade, dentre outros, são exemplos de herança quantitativa. Para a maioria destes, existem poucas informações sobre o número, posição cromossômica, magnitude de efeito e interações dos loci que controlam a sua expressão. Estes loci são chamados de QTL "Quantitative Trait Lócus", ou seja, são os loci que controlam a expressão de características quantitativas (ROTHSCHILD e SOLLER, 1999). A localização de QTL no cromossomo 6 de bovinos, local onde o gene para caseína está localizado, identificou marcadores relacionados a produção de gordura assim como da proteína (KUHN et al, 1999) e percentual de proteína, produção de leite e produção de gordura (VELMALA et al, 1999).

A avaliação das diferenças alélicas de genes específicos entre raças distintas é de grande importância para o melhoramento animal. O estudo de freqüência em uma população é necessário para que seja possível a associação entre polimorfismos e características quantitativas (FARIA et al,1999). Segundo Bordim et al (2001), a participação da kappa-caseína na composição protéica do leite justifica pesquisas sobre a correlação deste polimorfismo com a produção, assim como a composição deste. Grande parte das pesquisas desenvolvidas demonstra que o alelo B da kappacaseína em bovinos está correlacionado com maior produção de proteínas no leite, quando comparados ao alelo A da kappa-caseína (MEDRANO e AGUILARCORDOVA, 1990; VAN EENENNAAM e MEDRANO, 1991a; VAN EENENNAAM e MEDRANO, 1991b; ZSOLNAI e FESUS, 1997; STEVANOVIC et al, 2000).

Em bovinos, o genótipo BB da kappa-caseína foi associado com melhores características para processamento industrial do leite (MACKLE et al, 1999). O uso de leite de vacas com genótipo BB para kappa-caseína resultou em menor tempo de coagulação para o preparo de queijo, formação de coágulo com maior densidade devido ao menor tamanho da micela, assim 
como uma maior produção de queijo em relação ao leite de vacas com genótipo AA para kappacaseína (VAN EENENNAAM e MEDRANO, 1991a; VAN EENENNAAM e MEDRANO, 1991b). Sabendo-se que a dieta apresenta efeito mínimo sobre a composição protéica do leite, o aumento da produção de queijo pela modificação da proteína láctea pode ser alcançado mais rapidamente através da seleção de vacas com os genótipos BB para kappa-caseína assim como BB para beta-lactoglobulina (BOBE et al, 2004).

Desta forma, estas marcantes variações entre vacas de fenótipos diferentes podem resultar em alterações da matéria-prima para a fabricação de queijos e outros derivados lácteos, sendo possível o seu uso como ferramenta para a seleção genética de vacas leiteiras. Apesar de a composição láctea ser um dos fatores mais importantes para a indústria, algumas características tem igual relevância, como é o caso da estabilidade térmica do leite, que hoje é considerada um dos principais fatores na determinação da aptidão do leite para o processamento industrial

A estabilidade térmica do leite é caracterizada como sendo o tempo necessário para originar coagulação visível em determinado $\mathrm{pH}$ e temperatura, sendo esta a capacidade do leite em resistir à coagulação pelo calor, o que indica a sua aptidão para processamento. Esta pode ser conceituada como a capacidade do leite em conservar-se a altas temperaturas de processamento sem apresentar coagulação ou gelatinização visíveis (SINGH, 2004).

A variação da composição protéica do leite é considerada pequena para exercer efeito significativo sobre a estabilidade do leite, no qual os teores de uréia, citrato, cálcio, entre outros, figuram como componentes mais importantes nesta relação (SINGH, 2004). Apesar disso Robitaille et al (2001) relataram que o polimorfismo na expressão do gene da kappa-caseína influenciou a estabilidade do leite ao álcool. Assim, leite de animais com expressão BB precipitou em concentração acima do leite de animais com expressão AA. 


\subsection{Objetivos}

O objetivo geral do presente estudo foi avaliar o efeito do polimorfismo genético de kappacaseína sobre as características físico-químicas, composição e estabilidade do leite de rebanhos leiteiros de diferentes raças. Os objetivos específicos do presente estudo foram:

a) Caracterizar o polimorfismo do gene da kappa-caseína em rebanhos leiteiros comerciais das raças Holandesa e Girolanda;

b) Avaliar o efeito do polimorfismo genético de kappa-caseína sobre características físicoquímicas (acidez, pH e crioscopia), composição (gordura, lactose, sólidos totais, CCS, uréia, PB, PV, NNP, NNC) e estabilidade do leite. 


\subsection{Material e Métodos}

\subsubsection{Seleção dos rebanhos para coleta}

O presente experimento foi realizado, em sua fase de coletas de amostras, na região de Pirassununga-SP, onde foram selecionados 11 rebanhos leiteiros comerciais, entre os quais cinco contavam com animais da raça Holandesa e seis da raça Girolanda. Em média foram amostradas 122 vacas em lactação por rebanho, totalizando 1350 vacas amostradas em três períodos. Foram selecionados rebanhos leiteiros com adequado controle de dados, que permitiu a obtenção de informações relacionadas à produção, datas de parição, estágio de lactação e número lactações.

\subsubsection{Seleção das vacas}

Para a seleção das vacas amostradas foram utilizados os seguintes critérios: vacas de primeira, segunda ou terceira lactação; vacas entre $>30$ e <250 dias em lactação. Para as vacas da raça Girolanda, foram selecionados animais com graus de sangue entre 1/2, 3/4 e 3/8 Gir/Holandês. Foram excluídas as vacas com alterações visuais do leite detectáveis pelo teste de caneca de fundo escuro (mastite clínica) ou que tinham sido submetidas ao tratamento de mastite nas últimas duas semanas antes da coleta.

\subsubsection{Coleta de amostras de leite das vacas}

Foram coletadas três amostras individuais de leite das vacas em lactação dos rebanhos selecionados, nos seguintes períodos: coleta 1 (Setembro e Outubro de 2003: seco), coleta 2 (Junho e Julho de 2004: seco) e coleta 3 (Novembro e Dezembro de 2004: chuvoso). Adicionalmente, no momento da coleta foram registradas as seguintes informações individuais de 
cada vaca leiteira selecionada: idade, dias em lactação, regime de alimentação a que o animal estava submetido (pasto, pasto com suplementação ou confinado).

As amostras individuais de leite foram coletadas durante a ordenha da manhã, sendo representativa de toda a ordenha de cada animal. As amostras individuais foram coletadas em cada latão de ordenha, nos sistemas denominados balde ao pé, a partir do balão de medição durante a ordenha, ou pelo uso de dispositivos de medição por fluxo (tipo "True Type"), e armazenadas em tubos plásticos previamente higienizados até a realização das análises. Para as análises físico-químicas do leite, as amostras foram resfriadas em recipientes térmicos com gelo em escamas até a realização das mesmas, em no máximo 6 horas. Para as análises de composição do leite, realizadas por absorção infravermelha e para CCS, as amostras foram enviadas para o Laboratório de Fisiologia da Lactação da ESALQ - USP (Clínica do Leite) em no máximo 72 horas. Para as demais análises, as amostras de leite foram congeladas $\left(-20^{\circ} \mathrm{C}\right)$ até a realização das mesmas.

\subsubsection{Delineamento experimental e análise estatística}

Foi utilizado o delineamento experimental tipo blocos ao acaso generalizados (GOMES, 1985), onde os blocos foram formados pelas fazendas, avaliando-se então o efeito da raça (Holandesa e Girolanda), da estação do ano (verão e inverno) sobre as variáveis resposta (características físico-químicas, composição e estabilidade do leite). Os dados foram analisados usando o PROC GLM do SAS. A análise de variância foi realizada considerando-se os efeitos de raça nos animais amostrados e período do ano (seco ou chuvoso), além de suas interações. Os resultados de CCS (x 1000 céls/mL) foram transformados em escala logarítmica antes de ser submetidos à análise estatística. 


\subsubsection{Metodologias para análises}

\subsubsection{Determinação da composição do leite}

A composição do leite foi determinada no Laboratório de Fisiologia da Lactação da ESALQ - USP (Clínica do Leite), sendo as concentrações de gordura, lactose, sólidos totais analisados por absorção infravermelha, utilizando-se equipamento Bentley $2000^{\circledR}$ (BENTLEY, 1995a) e o nitrogênio uréico no leite $(\mathrm{mg} / \mathrm{dL})$, por método enzimático espectrofotométrico de trans-reflectância no equipamento ChemSpeck $150^{\circledR}$ (BENTLEY, 1998).

\subsubsection{Determinação das características físico-químicas do leite}

A determinação das características físico-químicas do leite - pH, acidez titulável (Dornic), densidade e crioscopia foram realizadas de acordo com a metodologia descrita por Pereira et al, (2001).

\subsubsection{Determinação de estabilidade do leite}

A determinação da estabilidade do leite foi realizada pela prova de resistência ao álcool, onde partes iguais de leite e álcool foram misturados e homogeneizados por cinco vezes até a realização da interpretação do resultado, que variou entre leite sem coagulação (SC), coagulação fina (CF) e leite coagulado (C). A graduação alcoólica utilizada foi de $68^{\circ} \mathrm{GL}, 70^{\circ} \mathrm{GL}, 76^{\circ} \mathrm{GL}$, $80^{\circ} \mathrm{GL}$ e $84^{\circ} \mathrm{GL}$ (WHITE e DAVIES, 1958a; IDF, 1969).

\subsubsection{Determinação do nitrogênio total (NT ou PB)}

A determinação da concentração de proteína do leite foi baseada na mensuração do NT pelo método de Kjeldahl, conforme metodologia descrita pela American Association Of Official 
Analytical Chemists (1995); método número 33.2.11; 991.20. O N foi então multiplicado pelo fator 6,38, para que os resultados fossem expressos em proteína bruta (PB) (BARBANO et al, 1990).

\subsubsection{Determinação do nitrogênio não-caseinoso (NNC)}

As frações de NNC e de caseína do leite foram determinadas no leite através de metodologia descrita por Lynch et al (1998). Resumidamente, a caseína do leite foi precipitada em $\mathrm{pH}=$ 4,6 usando-se solução de ácido acético e acetato de sódio. Após a precipitação, a caseína do leite foi separada por filtração e a concentração de $\mathrm{N}$ do filtrado (NNC) foi então determinada pelo método de Kjeldahl. Através da subtração da concentração de NT e NNC, foi determinada a concentração de caseína do leite.

\subsubsection{Determinação do nitrogênio não-protéico (NNP)}

As frações de NNP e de proteína verdadeira do leite foram determinadas no leite através de metodologia descrita por (LYNCH et al, 1998). Resumidamente, a proteína verdadeira do leite é precipitada em $\mathrm{pH}$ ácido usando-se solução de ácido tricloracético. Após a precipitação, a proteína verdadeira do leite foi separada por filtração e a concentração de $\mathrm{N}$ do filtrado (NNP) foi então determinada pelo método de Kjeldahl. Através da subtração da concentração de NT e NNP, foi determinada a concentração de proteína verdadeira do leite.

\subsubsection{Contagem de células somáticas do leite}

As amostras de leite foram coletadas de forma composta, acondicionadas em frascos de plástico e conservadas em bromopol, sendo enviadas para o Laboratório Clínica do Leite - 
Departamento de Produção Animal da ESALQ-USP (Piracicaba-SP), para a realização da contagem eletrônica de células somáticas $\left(\times 10^{3}\right.$ cels $\left./ \mathrm{mL}\right)$ por citometria de fluxo com equipamento Somacount $300^{\circledR}$ (BENTLEY, 1995b)

\subsubsection{Determinação do polimorfismo genético de kappa-caseína}

Foram colhidos aproximadamente $10 \mathrm{ml}$ de sangue da circulação periférica em tubo vacutainer heparinizado e estéril de cada animal selecionado, as quais foram resfriadas a $4^{\circ} \mathrm{C} . \mathrm{O}$ DNA da amostra foi extraído segundo o protocolo descrito por metodologia de Homppufer. As amostras de DNA extraídas foram submetidas à amplificação por PCR (polymerase chain reaction), os oligonucleotídeos iniciadores (primers) utilizados para tal amplificação foram sintetizados pela Invitrogen Custom Primers, conforme seqüência descrita por Pinder et al, 1991.

\section{5'GTGCTGAGYAGGTATCCTAG3'}

\section{5'GTAGAGTGCAACAACACTGG3'}

Tais primers amplificam uma região de 99 pares de base do éxon IV do gene da kappacaseína bovina. A região amplificada possui as substituições de nucleotídeos responsáveis pela diferenciação das variantes genéticas A e B. Cada reação de amplificação consistiu de tampão para PCR 1X (KCl $500 \mathrm{mM}$, Tris-Cl pH $8.3100 \mathrm{mM}), 0,1 \mu \mathrm{L}$ de cada primer (Invitrogen $\left.{ }^{\circledR}\right), 2,0$ $\mu \mathrm{L}$ de dNTP 0,125 mM, 0,1 $\mu \mathrm{L}$ Taq Polimerase (Cenbiot/RS, PHN/MG), 0,75 $\mu \mathrm{L} \mathrm{MgCl}_{2}$ (Cenbiot/RS, PHN/MG), 5,0 $\mu \mathrm{L}$ de DNA e água mili-Q qsp $25 \mu \mathrm{L}$. Em todas as reações de amplificação utilizou-se um controle (branco/sem DNA) para confirmar a ausência de contaminação na execução do sistema. As amplificações foram realizadas em termociclador PTC 100-MJ Research ${ }^{\circledR}$. O programa utilizado para amplificação do gene da kappa-caseína segue 
descrito: desnaturação inicial a $95^{\circ} \mathrm{C}$ por 5 min seguida por 35 ciclos de $95^{\circ} \mathrm{C}$ por $1 \mathrm{~min}, 57^{\circ} \mathrm{C}$ por 1 min e $72^{\circ} \mathrm{C}$ por 3 min com extensão final a $72{ }^{\circ} \mathrm{C}$ por 5 min seguida de $4^{\circ} \mathrm{C}$ por mais 5 min.

Após confirmação da amplificação das amostras por eletroforese, em gel de agarose a 2\%, em cuba horizontal de acrílico com tampão de corrida TBE 1 X a 100 volts por quarenta minutos. O produto da PCR $(20,0 \mu \mathrm{L})$, passou então pelo processo de RFLP (restriction fragment length polymorphism), ou seja, foi digerido e cortado pela enzima de restrição Hind III, sendo esta a enzima recomendada para a determinação dos genótipos segundo o protocolo descrito por Pinder et al (1991) e Cronin e Cockett (1993). A Hind III detecta um sítio de restrição no alelo B, gerando fragmentos de 65 e 34pb. A visualização de um fragmento de 99pb permite identificar o genótipo AA, os fragmentos de 34, 65 e 99pb identificam o heterozigoto $\mathrm{AB}$ e a presença dos fragmentos de 65 e 34pb identificam o genótipo BB. As amostras foram amplificadas assim como digeridas em placas próprias para PCR assim a presença de um de animal AB em cada placa demonstrava que a reação de digestão do material havia ocorrido sendo desta forma o controle do processo de digestão. Após a identificação dos polimorfismos genéticos do gene kappa-caseína bovina por meio da técnica de PCR-RFLP, obtiveram-se as freqüências genotípicas e alélicas para o rebanho estudado.

\subsection{Resultados e Discussão}

Ao se determinar o polimorfismo genético da kappa-caseína, verificou-se uma freqüência de 0,67 para o genótipo AA $(n=762), 0,31$ para $A B(n=356)$ e 0,02 para genótipo $B B(n=24)$ (Tabela 5). 
Tabela 5 - Distribuição da frequiência do polimorfismo do gene da kappa-caseína para as raças estudadas

\begin{tabular}{lccccc}
\hline \multirow{2}{*}{ Raça } & \multicolumn{3}{c}{ Polimorfismo kappa-caseína } & \multicolumn{2}{c}{ Alelos } \\
\cline { 2 - 6 } & AA & AB & BB & A & B \\
\hline Holandesa & 0,68 & 0,31 & 0,01 & 0,83 & 0,17 \\
Girolanda & 0,64 & 0,33 & 0,03 & 0,80 & 0,20 \\
\hline TOTAL & 0,66 & 0,32 & 0,02 & 0,82 & 0,18 \\
\hline
\end{tabular}

A maior freqüência do alelo A encontrada nos rebanhos estudados foi confirmada por outros pesquisadores em rebanhos brasileiros de origem zebuína (DEL LAMA e ZAGO, 1996; DA SILVA e DEL LAMA, 1997; FARIA et al, 1999; TAMBASCO et al, 2000; TAMBASCO et al, 2003). Kemenes et al (1999) ao analisar raças zebuínas brasileiras encontrou 0,93 em animais Gir e 0,92 para animais Guzerá. Do mesmo modo, Biase et al (2005) estudando animais Nelore encontraram 0,911 , reforçando que o rebanho brasileiro apresenta alta freqüência do alelo A. Os resultados obtidos por este experimento, assim como os demais acima citados confirmam a classificação sanguínea do gado realizada por Baker e Manwell (1980) e Manwell e Baker (1980). Tais autores relatam que, assim como os rebanhos britânicos, o rebanho zebuíno apresenta grande freqüência do alelo A. Em animais brasileiros, a menor freqüência do alelo B sugere que o uso de marcadores moleculares em programas de seleção assistida poderiam trazer benefícios a produção leiteira Da Silva e Del Lama (1997), assim como a indústria de produtos lácteos.

Del Lama e Zago (1996) sugerem que a alta freqüência do alelo A pode ser resultado da intensiva seleção para ganho de peso, a qual pode indiretamente ter afetado a frequiência do alelo 
A nas raças zebuínas, pois apenas os animais da raça Gir não foram selecionados com a finalidade de produzir carne.

No presente estudo, não foi observada diferença entre os valores de acidez titulável $\left({ }^{\circ} \mathrm{D}\right)$, pH e ponto crioscópico do leite quando para os diferentes polimorfos do gene da kappa-caseína (tabela 6). Ainda de acordo com resultados apresentados na tabela 6, não houve efeito significativo do polimorfismo genético de kappa-caseína sobre teores de gordura e sólidos totais, lactose, células somáticas e uréia do leite. Ngkwaihang et al (1986), estudaram 1908 vacas Holandesas em dois anos, relataram que animais kappa-caseína B apresentavam teor de gordura no leite maior que os animais kappa-caseína A. Entretanto, estes mesmos autores ao realizar trabalho semelhante, em 1990, em animais da raça Holandesa, observaram maior produção de gordura pelos animais A. Mostrando assim a inconstância de resultados com relação ao efeito de polimorfismo genético sobre as principais características de composição do leite.

Na tabela 7 estão apresentados dados referentes ao efeito do polimorfismo genético de kappa-caseína sobre composição protéica do leite. Não foi observado efeito significativo sobre nenhum componente protéico avaliado pelo presente estudo. Alguns autores esclarecem ausência de efeito das variantes do gene para kappa-caseína para quantidade de proteína produzida (HAENLEIN et al, 1987). Robitaille et al (2001), assim como no presente estudo, não encontraram efeito no percentual de caseína e na caseína produzida em animais de diferentes genótipos, entretanto estes mesmos autores observaram maior produção de kappa-caseína $(p<0,001)$ ao estudarem o perfil da caseína presente no leite. Os resultados do presente estudo diferem de algumas pesquisas desenvolvidas, que demonstram, ser o alelo B da kappa-caseína em bovinos, o responsável por maior produção de proteínas no leite, quando comparados ao alelo A 
(MEDRANO e AGUILARCORDOVA, 1990; ZSOLNAI e FESUS, 1997; STEVANOVIC et al, 2000).

Segundo Van Eenennaam e Medrano (1991a), Van Eenennaam e Medrano (1991b) e Ikonen et al (2004), o uso do leite de vacas com genótipo BB para kappa-caseina, resultou em menor tempo de coagulação para o preparo de queijo, formação de coagulo com maior densidade devido ao menor tamanho da micela assim como uma maior produção de queijo, devido a maiores teores de caseína em relação à proteína total em relação ao leite de vacas com genótipo AA para kappa-caseína. Da mesma forma Mackle et al (1999), ao estudarem interações entre polimorfismo genético e alimentação sobre as principais características de composição do leite, relatam que o efeito do polimorfismo genético só foi observado sobre composição protéica, sendo o genótipo BB para caseína e considerado melhor para a produção de queijo por elevar os teores de caseína do leite, aumento este observado da ordem de $23 \%$.

Ojala et al (1997), estudando o polimorfismo genético de caseína e lactoglobulina em 916 vacas Holandesas e 116 vacas Jersey, concluíram não haver efeito significativo sobre produção e composição do leite, porém os efeitos da interação dos genes estudados sobre as mesmas características foram significativos. 
Tabela 6 - Efeito do polimorfismo genético de kappa-caseína sobre características físico-químicas e de composição do leite

\begin{tabular}{|c|c|c|c|c|c|c|c|c|c|c|c|c|c|c|}
\hline \multirow{2}{*}{ Variável } & \multicolumn{6}{|c|}{ Holandesa } & \multirow{2}{*}{$P$} & \multicolumn{6}{|c|}{ Girolanda } & \multirow{2}{*}{$P$} \\
\hline & $\mathbf{n}$ & $\mathbf{A A}$ & $\mathbf{n}$ & $\mathbf{A B}$ & $\mathbf{N}$ & BB & & $\mathbf{n}$ & $\mathbf{A A}$ & $\mathbf{n}$ & $\mathbf{A B}$ & $\mathbf{n}$ & BB & \\
\hline Dornic $\left({ }^{\circ} \mathrm{D}\right)$ & 464 & 16,07 & 198 & 16,41 & 10 & 16,60 & NS & 298 & 16,94 & 158 & 16,80 & 14 & 17,79 & NS \\
\hline $\mathrm{pH}$ & 423 & 6,79 & 186 & 6,78 & 8 & 6,81 & NS & 308 & 6,74 & 161 & 6,74 & 14 & 6,74 & NS \\
\hline Crioscopia $\left({ }^{\circ} \mathrm{H}\right)$ & 429 & $-0,540$ & 194 & $-0,540$ & 9 & $-0,542$ & NS & 291 & $-0,540$ & 150 & $-0,540$ & 11 & $-0,539$ & NS \\
\hline Gordura (\%) & 438 & 3,32 & 201 & 3,39 & 10 & 3,10 & NS & 293 & 3,18 & 157 & 3,26 & 14 & 3,47 & NS \\
\hline Lactose (\%) & 447 & 4,47 & 203 & 4,46 & 10 & 4,45 & NS & 307 & 4,50 & 156 & 4,54 & 14 & 4,51 & NS \\
\hline Solidos (\%) & 441 & 11,89 & 200 & 11,89 & 10 & 11,43 & NS & 299 & 11,79 & 157 & 11,97 & 14 & 12,32 & NS \\
\hline $\mathrm{CCS} *$ & 469 & 5,34 & 211 & 5,33 & 10 & 5,28 & NS & 313 & 5,32 & 164 & 5,40 & 14 & 5,55 & NS \\
\hline
\end{tabular}

CCS expresso em Log CCS x1000 céls/mL

Tabela 7 - Efeito do polimorfismo genético de kappa-caseína sobre a composição nitrogenada do leite

\begin{tabular}{|c|c|c|c|c|c|c|c|c|c|c|c|c|c|c|}
\hline \multirow{2}{*}{ Variável } & \multicolumn{6}{|c|}{ Holandesa } & \multirow{2}{*}{$P$} & \multicolumn{6}{|c|}{ Girolanda } & \multirow{2}{*}{$\boldsymbol{P}$} \\
\hline & $\mathbf{n}$ & $\mathbf{A A}$ & $\mathbf{n}$ & $\mathbf{A B}$ & $\mathbf{N}$ & BB & & $\mathbf{n}$ & $\overline{\mathbf{A A}}$ & $\mathbf{n}$ & AB & n & BB & \\
\hline $\mathrm{PB}(\%)$ & 447 & 3,12 & 202 & 3,12 & 10 & 3,03 & $\mathrm{NS}$ & 295 & 3,10 & 157 & 3,13 & 14 & 3,15 & $\mathrm{NS}$ \\
\hline Uréia (mg/dL) & 459 & 17,50 & 208 & 17,18 & 10 & 16,35 & NS & 291 & 15,68 & 157 & 15,05 & 13 & 12,90 & NS \\
\hline EqNNP (\%) & 452 & 0,23 & 206 & 0,24 & 10 & 0,21 & NS & 306 & 0,23 & 158 & 0,22 & 13 & 0,21 & NS \\
\hline NNC (\%) & 451 & 0,13 & 202 & 0,12 & 9 & 0,13 & NS & 301 & 0,13 & 161 & 0,12 & 14 & 0,12 & NS \\
\hline PV (\%) & 445 & 2,90 & 202 & 2,89 & 10 & 2,82 & NS & 294 & 2,88 & 157 & 2,92 & 14 & 2,96 & NS \\
\hline Caseína (\%) & 445 & 2,35 & 202 & 2,36 & 10 & 2,32 & NS & 294 & 2,33 & 157 & 2,37 & 14 & 2,39 & NS \\
\hline EqNNC (\%) & 445 & 0,77 & 202 & 0,76 & 10 & 0,71 & NS & 294 & 0,77 & 157 & 0,77 & 14 & 0,77 & NS \\
\hline
\end{tabular}

EqNNP - expresso em equivalente nitrogênio não protéico (NNPx6,38) 
Na tabela 8 são apresentados dados referentes à estabilidade do leite frente à prova do álcool. Não foi observado efeito do polimorfismo genético de kappa-caseína sobre a graduação alcoólica responsável pela coagulação das amostras. Apesar de animais que apresentam $\mathrm{AB}$ como expressão alélica para esse gene apresentarem menor estabilidade, esta não se diferencia dos outros dois genótipos. Resultado este que difere do observado por Robitaille et al (2001), que observaram efeito da expressão gênica da kappa-caseína sobre a estabilidade do leite mensurada pela prova do álcool, em que animais que apresentaram maior expressão do alelo $\mathrm{B}$, produziam leites que se mostravam mais resistentes à precipitação. Outra conclusão dos autores foi que o $\mathrm{pH}$ da amostra teve maior efeito sobre a estabilidade do leite do que o observado pela expressão do alelo B.

Tabela 8 - Efeito do polimorfismo genético de kappa-caseína sobre estabilidade do leite.

\begin{tabular}{lccc}
\hline \multirow{2}{*}{ Polimorfismo da K-caseína } & \multicolumn{3}{c}{ PROVA DO ALCOOL } \\
\cline { 2 - 4 } & $\mathbf{N C *}(\boldsymbol{\%})$ & $\mathbf{C} * *\left({ }^{\mathbf{o}} \mathbf{G L}\right)$ & $\mathbf{D P}$ \\
\hline $\mathrm{AA}$ & 65,33 & 79,32 & 4,87 \\
$\mathrm{AB}$ & 66,13 & 78,78 & 5,22 \\
BB & 62,50 & 79,33 & 5,01 \\
\hline TOTAL & 65,19 & 63,34 & 4,83 \\
\hline$P$ & \multicolumn{3}{c}{0,618} \\
\hline \multicolumn{4}{c}{${ }^{* N C}-$ amostras que não apresentaram coagulação } \\
$* * \mathrm{C}-$ amostras que apresentaram coagulação
\end{tabular}




\subsection{Conclusão}

De acordo com os resultados obtidos no presente estudo, as seguintes conclusões podem ser enumeradas:

a) A freqüência do alelo A é maior do que a do alelo B para o gene da kappa-caseína, tanto em animais da raça Holandesa quanto Girolanda;

b) Identifica-se maior freqüência do genótipo AA e a menor para o genótipo BB em ambas raças: Girolanda e Holandesa;

c) Não se observa efeito do polimorfismo do gene da kappa-caseína sobre teores de gordura, sólidos totais, lactose, CCS e uréia do leite;

d) Não se observa efeitos do polimorfismo genético do gene para kappa-caseína sobre a composição protéica do leite;

e) A estabilidade do leite frente à prova do álcool não sofre influência do polimorfismo genético de kappa-caseína. 


\subsection{Referências Bibliográficas}

\section{AMERICAN ASSOCIATION OF OFFICIAL ANALYTICAL CHEMISTS. Official methods of analysis. Arlington, VA. 1995}

BAKER, C.M.A. e MANWELL, C. Chemical classification of cattle.1. Breed groups. Animal Blood Groups and Biochemical Genetics, v.11, n.3, p.127-150. 1980.

BARBANO, D.M., CLARK, J.L., DUNHAM, C.E., et al Kjeldahl method for determination of total nitrogen-content of milk - collaborative study. Journal of The Association of Official Analytical Chemists, v.73, n.6, p.849-859. 1990.

BENTLEY. Bentley 2000: Operator's manual p.77. 1995a.

BENTLEY. Somacount 300: Operator's manual p.12. $1995 \mathrm{~b}$.

BEQUETTE, B.J., BACKWELL, F.R.C. e CROMPTON, L.A. Current concepts of amino acid and protein metabolism in the mammary gland of the lactating ruminant. Journal of Dairy Science, v.81, n.9, p.2540-2559. 1998.

BIASE, F.H., GARNERO, A.D., BEZERRA, L.A.F., et al Analysis of restriction fragment length polymorphism in the kappa-casein gene related to weight expected progeny difference in nellore cattle. Genetics and Molecular Biology, v.28, n.1, p.84-87. 2005.

BOBE, G., FREEMAN, A.E., LINDBERG, G.L., et al The influence of milk protein phenotypes on fatty acid composition of milk from holstein cows. Milchwissenschaft-Milk Science International, v.59, n.1-2, p.3-6. 2004.

BORDIM, G., RAPOSO, F.C., CALLE, B., et al Identification and quantification of major bovine milk proteins by liquid chromatography. Journal of Chromatography, v.928, p.6376. 2001.

CRONIN, M.A. e COCKETT, N. Kappa-casein polymorphisms among cattle breeds and bison herds. Animal Genetics, v.24, n.2, p.135-138. 1993.

DA SILVA, I.T. e DEL LAMA, M.A. Milk protein polymorphisms in Brazilian zebu cattle. Brazilian Journal of Genetics, v.20, n.4, p.625-630. 1997.

DEL LAMA, S.N. e ZAGO, M.A. Identification of the kappa-casein and beta-lactoglobulin genotypes in brazilian bos indicus and bubalus bubalis populations. Brazilian Journal of Genetics, v.19, p.73-77. 1996. 
FARIA, F.J.C., GUIMARAES, S.E.F., LIMA, R.M.G., et al Polimorphism analysis of kappacasein gene on nelore females and effect on weaning weight of the calves. Arquivo Brasileiro de Medicina Veterinaria e Zootecnia, v.51, n.4, p.377-382. 1999.

GOMES, P. Curso de estatística experimental p.467. 1985.

HAENLEIN, G.F.W., GONYON, D.S., MATHER, R.E., et al Associations of bovine blood and milk polymorphisms with lactation traits - Guernseys. Journal of Dairy Science, v.70, n.12, p.2599-2609. 1987.

IDF. Control methods for sterilized milk. n.48, p.3. 1969.

IKONEN, T., MORRI, S., TYRISEVA, A.M., et al Genetic and phenotypic correlations between milk coagulation properties, milk production traits, somatic cell count, casein content, and ph of milk. Journal of Dairy Science, v.87, n.2, p.458-467. 2004.

KEMENES, P.A., REGITANO, L.C.D., ROSA, A.J.D., et al Kappa-casein, beta-lactoglobulin and growth hormone allele frequencies and genetic distances in Nelore, Gyr, Guzera, Caracu, Charolais, Canchim and Santa Gertrudis cattle. Genetics and Molecular Biology, v.22, n.4, p.539-541. 1999.

KUHN, C., FREYER, G., WEIKARD, R., et al Detection of qtl for milk production traits in cattle by application of a specifically developed marker map of bta6. Animal Genetics, v.30, n.5, p.333-340. 1999.

LYNCH, J.M., BARBANO, D.M. e FLEMING, J.R. Indirect and direct determination of the casein content of milk by Kjeldahl nitrogen analysis: Collaborative study. Journal of AOAC International, v.81, n.4, p.763-774. 1998.

MACKLE, T.R., BRYANT, A.M., PETCH, S.F., et al Nutritional influences on the composition of milk from cows of different protein phenotypes in New Zealand. Journal of Dairy Science, v.82, n.1, p.172-180. 1999.

MANWELL, C. e BAKER, C.M.A. Chemical classification of cattle.2. Phylogenetic tree and specific status of the zebu. Animal Blood Groups and Biochemical Genetics, v.11, n.3, p.151-162. 1980.

MEDRANO, J.F. e AGUILARCORDOVA, E. Genotyping of bovine kappa-casein loci following dna-sequence amplification. Bio-Technology, v.8, n.2, p.144-146. 1990.

MOODY, D.E., POMP, D. e NEWMAN, S. Characterization of DNA polymorphism their associations with growth and maternal traits in line 1 Hereford cattle. In: V World Congress on Genetics Applied to Livestock Production, v.21, p.221-224. 1994.

NGKWAIHANG, K.F., HAYES, J.F., MOXLEY, J.E., et al Relationships between milk protein polymorphisms and major milk constituents in Holstein-Friesian cows. Journal of Dairy Science, v.69, n.1, p.22-26. 1986. 
OJALA, M., FAMULA, T.R. e MEDRANO, J.F. Effects of milk protein genotypes on the variation for milk production traits of Holstein and jersey cows in California. Journal of Dairy Science, v.80, n.8, p.1776-1785. 1997.

PEREIRA, D.B.C.P., SILVA, P.H.F., COSTA JR, L.C.G., et al Físico-química do leite e derivados - métodos analíticos. Juiz de Fora-MG: EPAMIG. 2001. 234 p.

PINDER, S.J., PERRY, B.N., SKIDMORE, C.J., et al Analysis of polymorphism in the bovine casein genes by use of the polymerase chain-reaction. Animal Genetics, v.22, n.1, p.11-20. 1991.

ROBITAILlE, G., BRITTEN, M. e PETITCLERC, D. Effect of a differential allelic expression of kappa-casein gene on ethanol stability of bovine milk. Journal of Dairy Research, v.68, n.1, p.145-149. 2001.

ROTHSCHILD, M.F. e SOLLER, M. Candidate gene analysis to detect genes controlling traits of economic importance in domestic livestock. International Symposium on Animal Breeding and Genetics, p.219-242. 1999.

SAS. Sas user's guide statistics. v.5. 1985.

SINGH, M.K. Genetic gain for milk yield in closed herds of Karan Fries and Karan Swiss cattle. Indian Veterinary Journal, v.81, n.6, p.654-657. 2004.

STEVANOVIC, M., STANOJCIC, S., DJUROVIC, J., et al Molecular marker technologies and selection for the traits of economic interest. Biotechnology in annimal husbandry, v.16, n.1-2, p.25-34. 2000.

TAMBASCO, D.D., DE ALENCAR, M.M., COUTINHO, L.L., et al Molecular characterization of a Nellore beef cattle sample using microsatellites and candidate genes. Revista Brasileira de Zootecnia-Brazilian Journal of Animal Science, v.29, n.4, p.10441049. 2000.

TAMBASCO, D.D., PAZ, C.C.P., TAMBASCO-STUDART, M., et al Candidate genes for growth traits in beef cattle crosses Bos Taurus x Bos Indicus. Journal of Animal Breeding and Genetics, v.120, n.1, p.51-56. 2003.

VAN EENENNAAM, A. e MEDRANO, J.F. Milk protein polymorphisms in California dairy cattle. Journal of Dairy Science, v.74, n.5, p.1730-1742. 1991a.

VAN EENENNAAM, A.L. e MEDRANO, J.F. Differences in allelic protein expression in the milk of heterozygous kappa-casein cows. Journal of Dairy Science, v.74, n.5, p.1491-1496. 1991b.

VELMALA, R.J., VILKKI, H.J., ELO, K.T., et al A search for quantitative trait loci for milk production traits on chromosome 6 in Finnish Ayrshire cattle. Animal Genetics, v.30, n.2, p.136-143. 1999. 
WHITE, J.C.D. e DAVIES, D.T. The relation between the chemical composition of milk and the stability of the caseinate complex.4. Coagulation by heat. Journal of Dairy Research, v.25, n.2, p.281-296. 1958.

ZSOLNAI, A. e FESUS, L. Enhancement of PCR-RFLP typing of bovine leukocyte adhesion deficiency. Biotechniques, v.23, n.3, p.380-382. 1997. 